\title{
Molecular Pathways of Glioblastoma and Glioblastoma Stem Cells
}

\author{
Cho-Lea Tso \\ Surgical Oncology, University of California, Los Angeles \\ United States of America
}

\section{Introduction}

Glioblastoma (GBM, WHO grade IV) is a type of highly malignant brain tumor that infiltrates the brain extensively and remains virtually incurable despite being treated with gross total resection and post-operative adjuvant radiation and chemotherapy. The vast majority of patients with GBM will always develop tumor recurrence. The tumor's location, its unique feature of high motility, and its protection by the blood brain barrier make certain therapies that are effective for some other cancers ineffective against brain tumors. Overall, the 5-year survival rate is less than $10 \%$, with a final mortality rate of close to 100 percent. The molecular mechanisms that underlie persistent tumorigenesis and treatment resistance are still poorly understood. A genome-wide expression profile analysis revealed that besides those genes associated with cell proliferation, inflammation, angiogenesis, and extracellular matrix (ECM) remodeling, a series of genes linked with neuroepithelial stem cells, mesenchymal stem cells, skeletal/cartilage development, morphogenesis, and organogenesis, were determined to be overexpressed when compared with normal brain tissue, implicating that a tissue regeneration/repair-like program is constantly activated in GBM tumors. A subset of GBM develops from lower-grade gliomas and can thus be clinically classified as "secondary," whereas some GBM occur with no prior evidence of a lower-grade tumor and can be clinically classified as "primary." Substantial genetic differences between these groups of GBM have been identified. Moreover, a molecular classification study indicated that both treatment-refractory and untreated primary GBM tumors are clustered in a group segregated from treated and untreated secondary GBM tumors, and supports the view that GBM subtypes may have derived from a distinct cell-oforigin, which is resistant to conventional therapy, therefore allowing for re-seeding tumor with molecular properties similar to untreated tumors. Thus, post-treatment tumor recurrence may mimic the scenario of post-injury tissue repair. Many adult tissues undergo renewal after injury, and hence require a new supply of cells originating from specialized tissue stem cells with the capability to undergo self-renewal and differentiation to repair damaged tissue. Recently, glioblastoma stem cells (GSC) or glioblastoma stem-like cells (GSLC), a minor subpopulation within tumor mass, were isolated and characterized as tumor-initiating cells and were hypothesized to be responsible for post-treatment recurrence because of their enhanced radio-/chemo-resistant phenotype and ability to reconstitute the original tumor tissue when grafted into mice. In contrast to the hyperproliferative, 
inflammatory, and hyperangiogeneic properties seen in GBM tumors, molecular analysis by gene expression profiling revealed that GSC possess neuroectodermal properties and express molecular signatures of radial glial cells (RGC) and neural crest cells (NCC), as well as portray a migratory, quiescent, and slow-growing phenotype that characterizes tumor suppressor properties. Based on the tumor stem cell model and theory, conventional cell cycle-targeted radio-chemotherapy, which aims to kill fast-growing tumor cells, would then be unable to eliminate post-operative remaining tumorigenic cells that possess quiescent stem cell properties. Thus, in order to prevent tumor recurrence, a strategy targeting essential gene pathways of GSC must be identified and incorporated into the standard treatment regimen. Identifying intrinsic and extrinsic cues, by which GSC maintain tumorigenic capacity and antiapoptotic feature to sustain tumorigenesis may highlight novel therapeutic strategies to greatly diminish the recurrence rate of GBM and provide potentially curative strategies for treating brain cancers. In this chapter, we review molecular properties of GBM tumors and GSC. We also summarize molecular signaling pathways that have been relatively well-studied in GSC and are essential for maintaining GSC stemness, tumorigenic capacity, and radio-chemoresistant phenotype.

\section{Molecular properties of glioblastoma}

\subsection{Genetic and clinical pathways to glioblastomas}

GBM remains refractory to conventional therapy. The histopathologic features that distinguish it from lower-grade astrocytic tumors are the presence of cellular atypia, mitotic figures, necrotic foci with peripheral cellular pseudopalisading, and microvascular hyperplasia (1). Two subgroups of GBM have been established based on clinical experience and have been affiliated with distinct genetic mechanisms of tumorigenesis. Secondary GBM, also known as progressive GBM, develop slowly through progression from low-grade glial tumors (WHO grade II) or anaplastic glial tumors (WHO grade III) and frequently display p53 mutation (chromosome 17$)(\sim 65 \%)$ and amplification or overexpression of platelet-derived growth factor receptor (PDGFR), but not epidermal growth factor receptor (EGFR) (2-3). Additionally, progression to secondary GBM often accompanies an allelic loss at chromosome 19q, 17p, and 10q, and a loss of expression of deleted-in-colorectalcarcinoma gene (DCC) ( 50\%) but rarely include PTEN mutations (5\%) (4-6). The p53 mutation is usually found in the low-grade lesions, indicating p53 alteration is an early event in astrocytoma progression (7). PDGFR amplification or overexpression is also present at the early stages suggesting that it may have a role in the progression of these tumors. In contrast, loss of heterozygosity for the retinoblastoma-1 (RB1) gene was found in high-grade astrocytomas $(25 \%)$ but not in low-grade astrocytomas, indicating disruption of the RB pathway is likely a significant event in the malignant transformation to GBM (8). On the other hand, primary GBM, also known as de novo GBM, seem to develop rapidly and manifest high-grade lesion from the outset and are genetically characterized by EGFR amplification/overexpression (chromosome 7$)(\sim 60 \%)$, a simultaneous loss of chromosome 10, but rarely a concurrent p53 mutation. The most common EGFR gene mutation in primary GBMs is EGFRvIII, a variant lacking exons 2-7 (corresponding to cDNA nucleotides 275-1075 encoding amino acids 6-273), which results in a truncated cell surface receptor with ligand-independent constitutive tyrosine kinase activity (9-11). This mutation presumably occurs through alternative splicing or gene rearrangements (12-13) and leads to the loss of binding activation by its normal ligand, EGF and TGF-a (14-15). Mouse double 
minute 2 (MDM2) amplification that neutralizes p53 activity (16), is observed in more than $50 \%$ of primary GBM, but rarely in secondary GBM. Additionally, CDKN2A (p16INK4a) deletion, PTEN mutation, $\mathrm{Rb}$ protein alterations and loss of all or a portion of chromosome 10 are frequently seen in primary GBM (17-18). p16INK4a deletion is infrequent in secondary GBMs and its deletion and p53 mutation appear to be two mutually exclusive events in GBMs (19). Primary GBMs account for the vast majority of cases $(60 \%)$ and typically occur in the elderly ( $>50$ years old), whereas secondary GBMs, are less common $(40 \%)$ and typically develop in younger patients $(<45$ y) (4). Primary and secondary GBMs are indistinguishable to the neurosurgeon as well as neuropathologist, and the clinical management of these two GBM subtypes is identical. To date, temozolomide (TMZ) administered daily with radiation therapy (RT) for six weeks, followed by adjuvant TMZ for six months, has become standard therapy for patients with newly diagnosed GBM.

\subsection{Genetic characteristics of GBM link to prognosis}

The overall prognosis for patients with GBM is extremely poor. However, a small proportion of patients show prolonged survival. A study indicates that different gliomaassociated genomic aberrations may serve as prognostic markers in combination with histopathological findings (17). The use of comparative genomic hybridization (CGH)-based analysis of 20 primary GBMs suggests that loss of chromosome 10 and gain/amplification in chromosome 7 are most frequently observed in primary GBMs and are associated with microvascularization and poor prognosis (17). In contrast, the combination of chromosome $1 \mathrm{p}$ and 17p13-p14 and 19q deletions are associated with a longer survival time $(5,17,20-21)$. The analysis of loss of heterozygosity $(\mathrm{LOH})$ on chromosomes $19 q, 1 p$, and $13 q$, using polymorphic microsatellite markers, however, has indicated that $\mathrm{LOH}$ on chromosome $19 \mathrm{q}$ was frequently found in secondary GBMs (50\%) but rarely detected in primary GBMs (20), suggesting that tumor suppressor gene(s) located on chromosome $19 q$ are frequently involved in the progression from a low-grade astrocytoma to secondary glioblastoma, but do not play a major role in the evolution of primary glioblastomas. Clinical trials indicated that patients whose tumor had a methylated promoter for the gene encoding O-6methylguanine-DNA methyltransferase (MGMT), were more likely to benefit from the addition of TMZ to RT (22-23). A recent study further showed that pattern of, and time to, recurrence after TMZ concomitant with and adjuvant to radiotherapy are strictly correlated with MGMT methylation status (21). Recently, genomewide mutational analysis of GBM revealed somatic mutations of cytosolic isocitrate dehydrogenase 1 gene (IDH1), which catalyzes the oxidative decarboxylation of isocitrate to a-ketoglutarate, most frequently in WHO grade II and III astrocytomas and secondary GBM but rarely in primary GBM (22-23), and patient tumors with IDH1 or related mitochondrial IDH2 mutations had a improved clinical prognosis than those with wild-type IDH genes $(25,27)$. It is suggested that IDH mutation is a highly prognosis predictor and selective molecular signature of secondary GBM (28-29).

\subsection{Molecular classification of glioblastoma subtypes}

Identification of chromosomal abnormalities and cancer-associated genes in solid tumors is becoming easier as genome-wide analysis technologies improve and as the genome sequence is being completed. These technologies allow for genome-wide data acquisition in study of cancer genetics and biology, particularly in analysis of complex expression 
patterns, in a rapid and efficient fashion. Moreover, since the expression of thousands of genes is analyzed simultaneously, we can expect to obtain more comprehensive information underlying the interactions of genes related to malignant transformation as well as crucial clues about alteration in the relevant genetic and biological networks (30). Since the genetic basis of human cancer is combinatorial, this approach becomes especially important when combined with computational technology (31). Likewise, genomic mutation (e.g. deletions, inversions, chromosome re-arrangement, amplification, promoter mutation) and posttranslational modifications of proteins are the key factors that induce and maintain the malignant transformation of cancer. The success of using gene expression patterns to study cancer will depend largely on how much they reflect genomic changes. If a significant portion of the effects of genomic abnormalities can be reflected at the RNA level, the gene expression patterns will be highly informative and can be analyzed to explain the molecular mechanisms underlying the pathological development and behavior of cancers (32). GBM tumor heterogeneity is likely to play a significant role in explaining the unsuccessful treatment modalities. Therefore, molecular classification with large-scale expression assays will be more prognostically and therapeutically significant (33-34) since comprehensive and unbiased information can be obtained and would allow for the development therapies specifically tailored to each subtype. Multiple studies also indicate that gene expressionbased classification of malignant gliomas correlates better with survival than histological classification (35). Successful integration of molecular/genetic data into tumor status must be descriptive and partially explain known tumor behavior, pathology, and resistance to therapy, as well as provide an insight to how the deregulation of multigene networks leads to tumor development, progression and treatment resistance $(32,36-37)$.

\subsubsection{Glioblastoma subtypes express distinct transcription profiles}

To identify whether molecular profiling can distinguish GBM subtypes, we and others have performed genome-wide microarray expression profiling and identified molecular subtypes that express distinct genes associated with tumor progression and predict clinical outcome better than histological class $(35,37-38)$. In general, using molecular profiling, GBM can be classified into three major subtypes include proliferative, mesenchymal and neuronal phenotypes (38-39), and the poor prognosis tumor subtypes are distinguished by the molecular markers of proliferation or mesenchymal/ECM/angiogenesis, which the majority is associated with losses on chromosome 10 that span 10q23.3 and gain on chromosome 7 . In particular, most cases of mesechymal GBM had relative losses at all loci on chromosome 10 and gains of all loci on chromosome 7, whereas proliferative tumors had more heterogeneous pattern of losses chromosome 10 (38). However, upon recurrence, GBM tumors tend to shift toward mesenchymal phenotype $(38,40)$. In order to elucidate whether primary and secondary GBM subgroups use distinct molecular pathways as well as identify gain-of-function genes that are associated with acquisition of malignant features of GBM subtypes, we have performed a large-scale DNA microarray analysis to compare the mean level of normalized transcript levels in each of the two clinically defined GBM groups versus the grade II and III astrocytomas. We have identified shared and non-shared GBMassociated gene (GAGs) over-expressed by respective subtype (40). As anticipated, shared GAGs reflect common characteristics of hyperproliferation, hypervascularity, and apoptotic resistance in both GBM subgroups, whereas GAGs distinct to primary or secondary tumors provided information on the heterogeneous properties and apparently distinct oncogenic 
mechanisms of these tumors. Secondary GBM-associated GAGs were mostly related to the mitotic cell cycle (Figure 1A), which corresponds to the fact that secondary GBM have high frequencies of TP53 and Rb mutations (2-3). Moreover, secondary GAGs reflect the causes and effects of such genotypic and phenotypic changes. Therefore, the molecular properties of secondary GBM support the notion that mutation or dysfunction of cell cycle regulators would be the major mechanism responsible for the development of malignant phenotype in secondary GBM. In contrast, primary GAGs highlight genes typical of a stromal/inflammatory response and are strongly associated with invasive phenotype, suggesting the importance of extracellular signaling (Figure 1B). The molecular properties of primary GBM thus support the view that the interplay between GBM derived bone/cartilage-associated factors and tumor-associated stromal cells play a key role in the malignant transformation of primary GBMs. To rule out the possibility that the distinct GBM progression-associated genes identified between the two subgroups are due to selection pressure (e.g. radiation or chemotherapy), we further conducted clustering-based analysis of a set of primary GBM $(n=13)$ that are recurrent and had prior treatment and secondary GBM $(n=12)$ samples that had been treated during grade step prior to tumor sampling, using these identified GAGs. The results indicate that both tumor subtypes, regardless of prior treatment, cluster within their clinical grouping based on gene expression of the selected GAGs (Figure 2). Of note, 85\% of recurrent primary GBM are clustered to mesenchymal GBM and $83 \%$ of secondary GBM are clustered into cell-cycle GBM, indicating that prior treatment is not disrupting this identified gene expression signature of primary and secondary GBM nor driving the selection of the genes. These data therefore support the notion that diverse mechanisms and properties underlying distinct transformation events or perhaps distinct cells of origin of GBM subtypes.

\subsubsection{Primary glioblastoma express mesechymal stem cell properties}

The most striking observation in the molecular properties of primary GBM among all is the series of genes highly expressed in mesenchymal tissues, but not in neural or glial cells, were identified. These overexpressed genes are related to osteogenesis and chondrogenesis (e.g. cartilage glycoprotein-39/YKL-40, chitinase 3-like 2, glycoprotein $\mathrm{nmb}$, lysyl oxidase, lung type-I cell membrane-associated glycoprotein, collagen type $\mathrm{V}$, VI, biglycan, mesenchyme homeobox 2 , and fatty acid-binding protein). These molecular properties characterized a mesenchymal phenotype of these glial tumors. To access gene pathways that are potentially associated with tumor development of primary GBM, a comparative analysis of primary GBM $(n=46)$ relative to normal brain tissue $(n=10)$ was performed. As anticipated, genes that were previously identified as primary GBM progression-associated genes reappeared in this gene list, which reflected the status of inflammation, coagulation, immune/complement responses, angiogenesis, and ECM remodeling (40, Figure 1B). Strikingly, a new series of genes linked with neural stem cells (NSC), mesenchymal stem cells (MSC), skeletal/cartilage development, morphogenesis, organogenesis, and embryonic neuroepithelial stem cells was determined. It thus implicates that a tissue regeneration/repair program is constantly activated in GBMs (Figure 3). Furthermore, a subset of primary GBM tumor-derived tumor lines expresses cellular markers that are associated with MSC (CD90, CD105, CD29, and CD44) and that GBM cell cultures can be induced to differentiate into multiple mesenchymal lineage-like cell types, including adipocytes, chondrocytes, and osteocytes (41). These findings suggest 


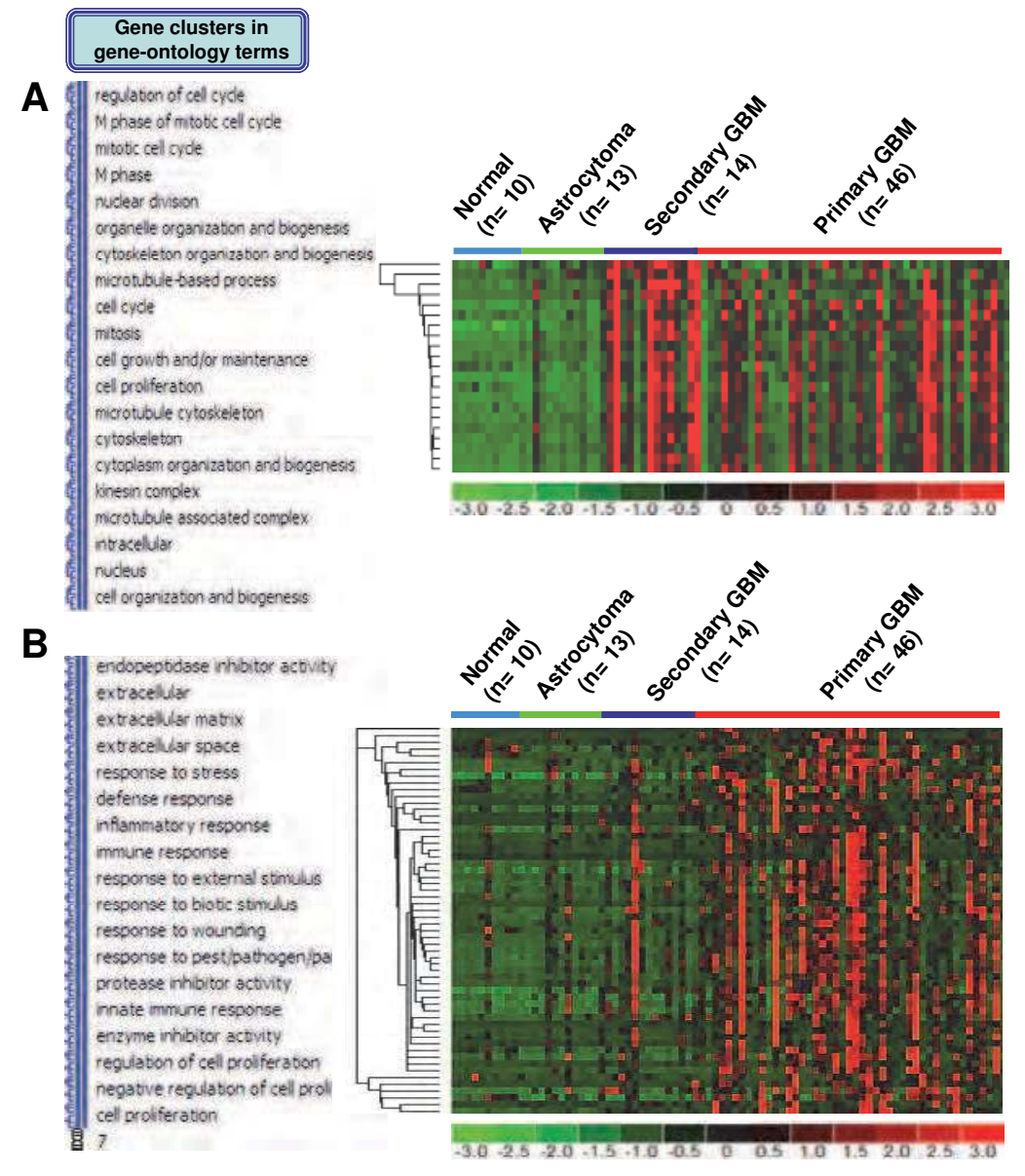

Fig. 1. Glioblastoma-associated genes (GAGs) overexpressed in GBM subtypes relative to lower grade gliomas. All plots show normalized gene expression values converted into a heat map. The $\log 2$ of the fold difference is indicated by the heat map scale at the bottom of the Figure. Each column is an individual tissue or tumor sample organized into histologic groups defined at the top of the figure. Each row is a single probe set measurement of transcript abundance for an individual gene. All genes were filtered to select transcripts with 2.5-fold or higher expression in the respective GBM group relative lower grade astrocytomas (P value $<0.05$, t-test). A. GAGs overexpressed uniquely in secondary glioblastomas: 21 secondary GAGs were defined as being uniquely detected with a $>2.5$-fold overexpression in the secondary GBM group compared with the lower-grade astrocytomas and not overexpressed within the primary glioblastoma group. B. GAGs overexpressed uniquely in primary GBM: 58 primary GAGs were defined as overexpressed 2.5-fold relative to lower-grade astrocytomas and not detected in the secondary glioblastomas comparison using the same criteria. Functional categories of gene clusters in gene-ontology (GO) terms were shown and were analyzed using a GO annotation-based gene function enrichment analysis (d-chip software). Gene description listed in Figure 2. 


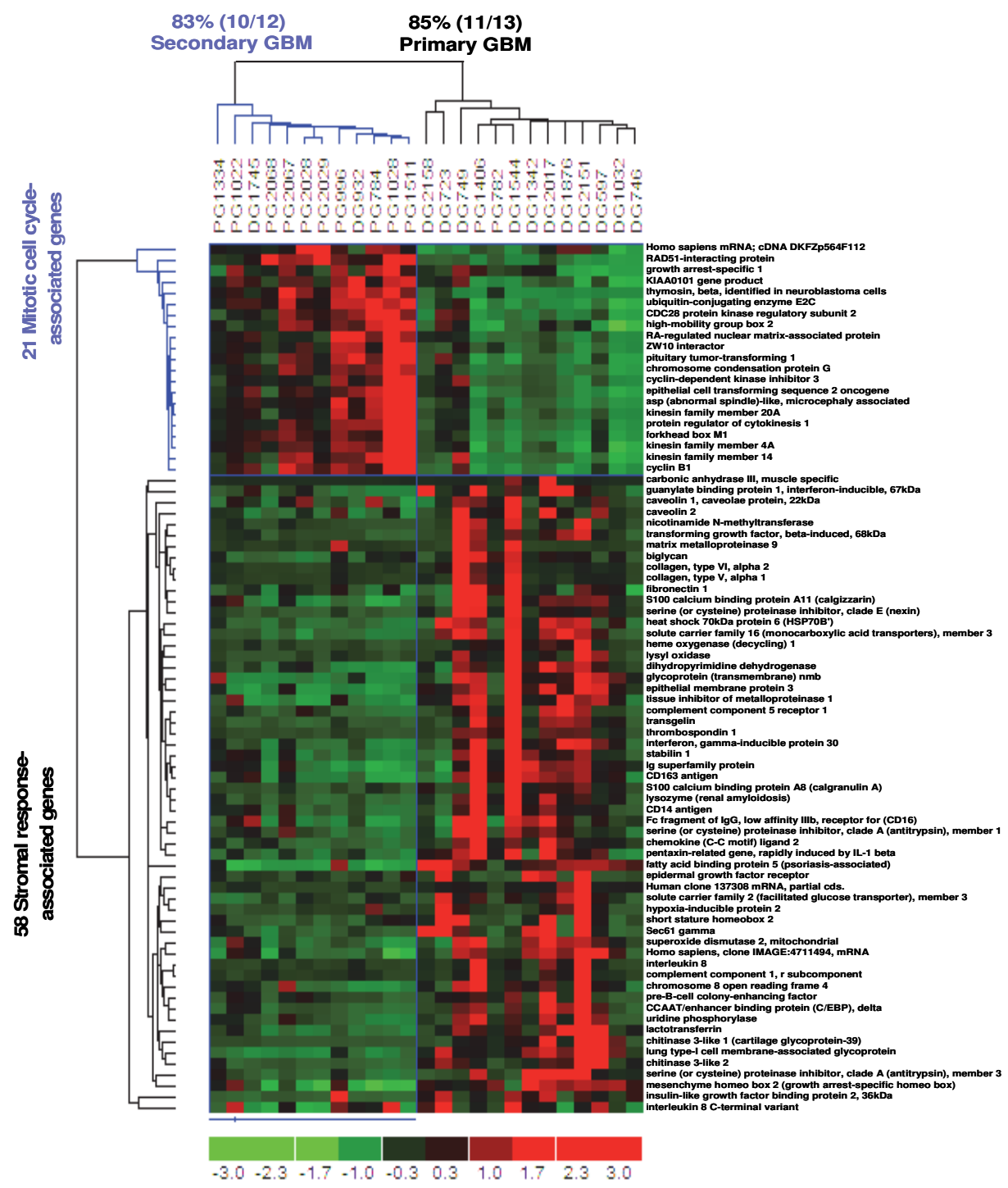

Fig. 2. Unsupervised sample clustering of primary and secondary GBM that are recurrent and had treatment using 21 secondary GAGs (Figure 1A) and 58 primary GAGs (Figure 1B). Distinct GAGs segregated GBM subtypes, suggesting they may be repopulated by GBM stem cells with distinct molecular properties. $P G=$ progressive/secondary $G B M . D G=$ de novo/primary GBM. 


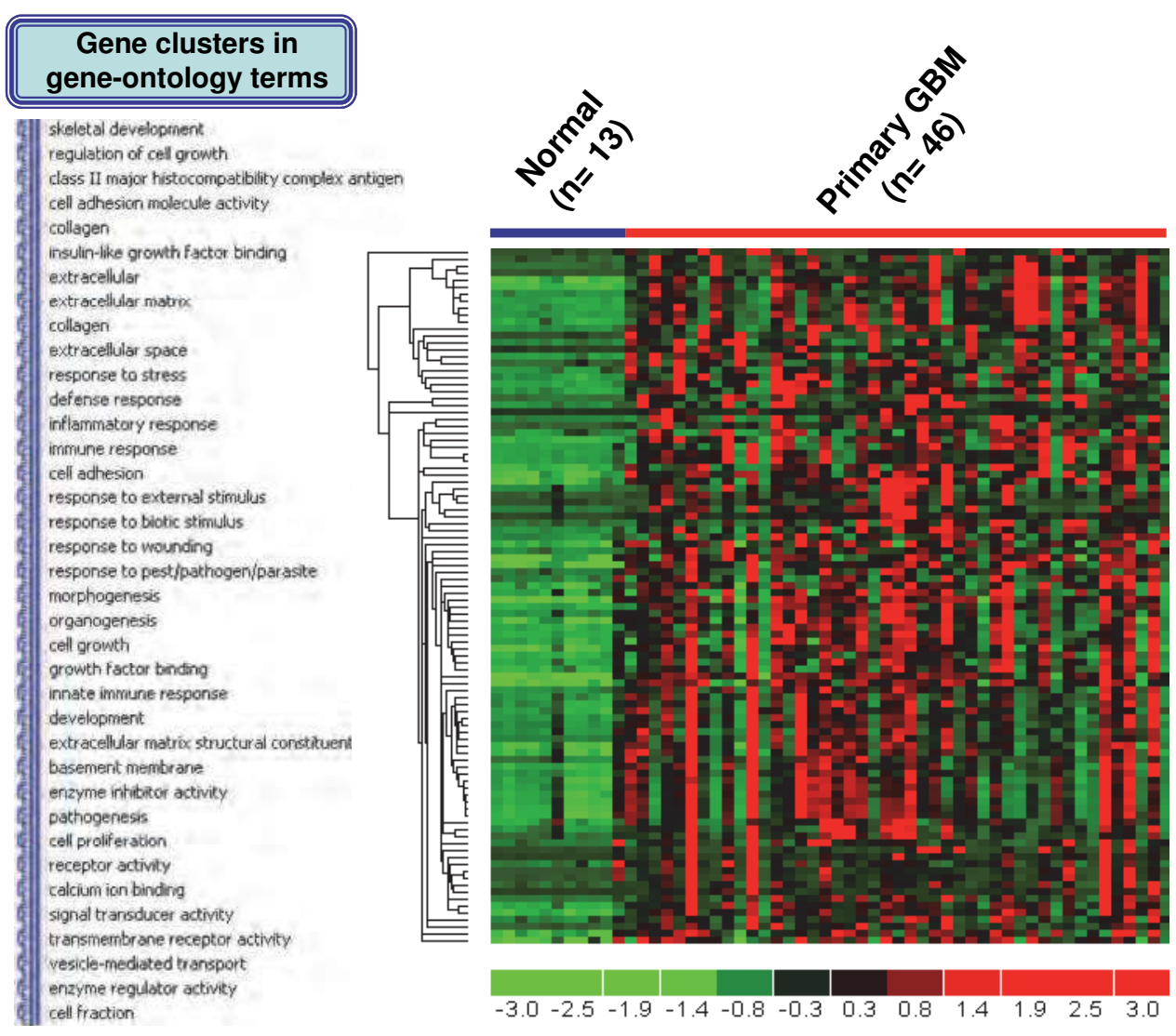

Fig. 3. A comparative analysis of gene expression profiles in primary GBM $(n=46)$ and normal brain tissue $(n=10)$. Analysis was based on a cutoff of a 2.5 -fold increase in relative expression $(\mathrm{P}<0.05)$. Top 100 primary GBM-associated genes expressed at higher levels compared with normal brain tissue were extracted. Functional categories of gene clusters in gene-ontology (GO) terms were shown. 
that either a subset of primary glioblastomas derives from transformed stem cells containing MSC-like properties and retains partial phenotypic aspects of a MSC nature in tumors, or that GBMs activate a series of genes resulting in mesenchymal properties of the cancer cells to effect sustained tumor growth and malignant progression. Since primary GBM express both NSC (e.g. nestin, SOX2) and MSC makers, it is hypothesized that a subset of GBM tumors may be derived from neural crest-stem-like cells (41). The lack of MSC-like properties in secondary GBM may suggest that they originate from a different cell type of cellular origin. Further characterization of stem-like cells in GBM tumors would help to identify new targets and subsequently develop new therapeutic strategies to delay tumor progression and prevent tumor regeneration.

\section{Glioblastoma stem cells}

\subsection{Glioblastoma contain tumorigenic stem -like cells}

Tumorigenic, stem-like GBM cells, or so-called glioblastoma stem cells (GSC) have been recently isolated and characterized as GBM tumor-initiating cells by multiple groups (4246). Although CD133/prominin, a normal NSC marker, is not an obligatory marker for GSC (46-47), CD133 was first applied as a surface marker for isolation and enrichment of GSC (42, 44-46, 48-49). Other surface markers are also reported to be used for GSC isolation and enrichment, including Musashi homolog 1 (MSI1) (50), and A2B5 (51). Through studies in both in-vitro and in-vivo GSC functional models, several essential genes and signaling pathways for maintaining tumorigenic potential have been implicated. At the functional level, GSC behave in ways similar to tissue stem cells, are capable of self-renewal and differentiation, and reconstitute the tumor tissue when grafted into mice. GSC possess a multi-lineage differentiation capacity also support for the hypothesis that cancer hierarchy is a result of developmental diversity among cancer cells in different states of differentiation (52-54). However, it is plausible that multiple genetic and/or epigenetic instabilities that take place within tumor stem cells might prevent progeny from undergoing non-proliferative terminal differentiation, leading to uncontrolled tumor growth (55-57). Tumors initiated in mouse brain by injection of patient-derived GSC often recapitulate the histopathological features of the patient tumors from which the cells were derived, indicating the ability to self-renew and reproduce the cellular heterogeneity found in human GBM tumors (44-45, 47-48). Uniquely, we found GSC isolated from treatment-refractory recurrent GBM tumors can spontaneously migrate radially outward from tumor spheres that they initiated and populated in cultures followed by spread out over the surface of the culture dish and form the secondary tumor spheres without additional factors added into the culture to influence the behavior of cells (Figure 4). This in-vitro observation suggests that the migratory nature of GSC is likely to be an intrinsic property that reflects inherently migratory properties of the GBM tumor of origin. Likewise, an intracranial injection of these GSC leads to the development of YKL-40+ infiltrative tumors that display hypervascularity and pseudopalisading necrosis-like features in mouse brain (Figure 4). Thus, it is possible that tumor recurrence in the secondary site may be due to tumor stem cells escaping from primary treatment, migrating out of core mass, infiltrating adjacent brain tissue, and continuing seeding a new tumor. Importantly, GSC were shown to resist the effects of ionizing radiation and chemotherapy (58-59) with a marked increase in activation of several checkpoint proteins in response to DNA damage, pointing to they 
may be responsible for the post-treatment tumor recurrence. Thus, identification of genes and pathways confer the migratory ability, anti-apoptotic features, and tumorigenic capacity of GSC would be essential for better understanding GSC and identifying potential targets in order to eradicate and prevent them from regenerating a new tumor.
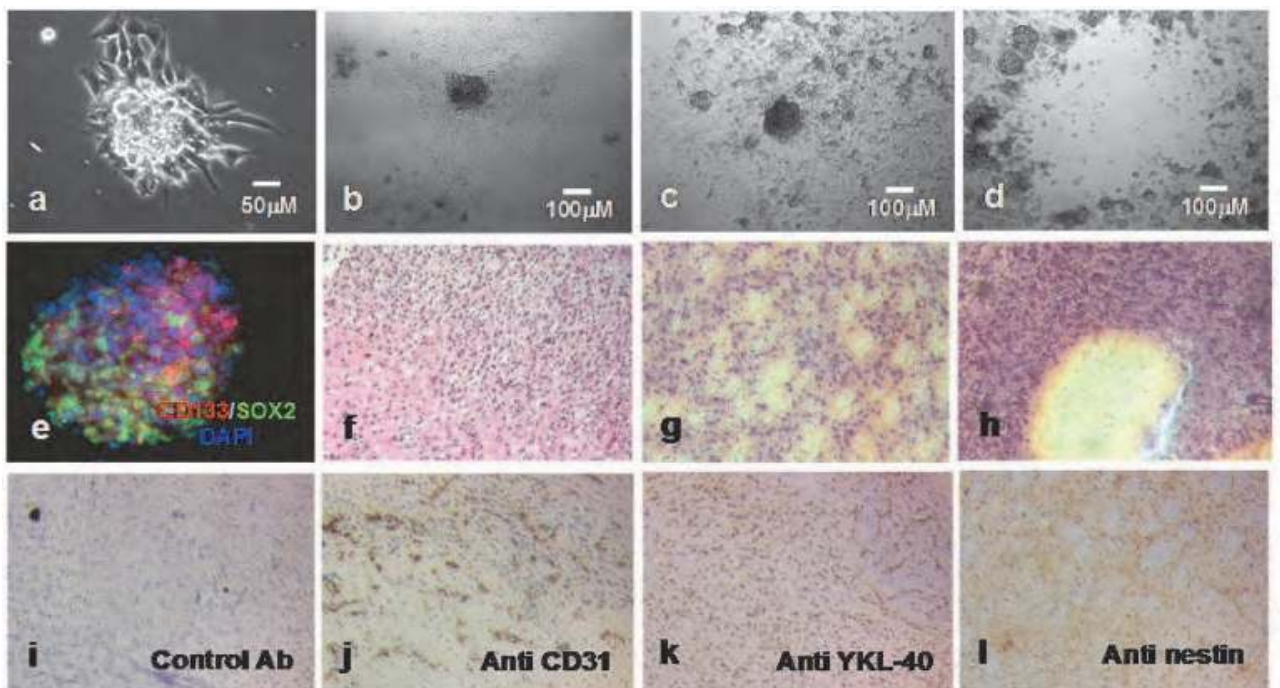

Fig. 4. Patient-derived glioblastoma stem cells (GSC) are highly motile cells and are capable of populating tumor spheres in cultures and initiating an infiltrating tumor in mouse brain. GSC isolated from treated and recurred tumor possess the ability to clonally self-renew, form primary tumor sphere (a), migrate outward (b), form secondary tumor spheres in secondary sites (c), and display pseudopalisading necrosis-like morphology (d). Immunofluorescent staining showed GSC spheres co-express CD133 and SOX2 (e) and can be propagated in cultures for indefinite passages. Brain tissues from mice injected with GSC display invasive growth of gliomas with diffuse infiltration into the surrounding tissue and exhibit hypercellular zones surrounding necrotic foci (f-h). Immunohistochemistry staining showed positivity in CD31/platelet endothelial cell adhesion molecule, YKL-40, and nestin, indicating an angiogenic progression of gliomas (i-1).

\subsection{Molecular properties of tumorigeneic glioblastoma stem cells}

Isolation and characterization of tumorigenic GSC derived from treatment-refractory GBM tumor may have a clinical implication of identifying innovative molecular targets for the development of a more effective treatment protocol. Particularly, elucidation of essential gene pathways of GSC that confer sustained self-renewal, cell migration and cell survival will be vital important for targeting and preventing of GSC mediated-tumor recurrence. Gene expression profile analysis revealed that purified, tumorigenic CD133+ GSC derived from treatment-refractory recurrent brain tumors possess neuroectodermal properties and portray astrogliogenic and chondrogenic potential. Moreover, CD133+GSC express molecular signatures for multiple adult stem cells, including RGC (e.g. fatty acid binding protein 7 , secreted protein acidic and rich in cysteine-like 1), NCC (e.g. endothelial 3, Distal-less homeo 
box 5/6, v-myc myelocytomatosis viral-related oncogene), NSC (e.g. SOX2, nestin), MSC (e.g. CD44, CD105), and stem cells in the small intestine and colon (e.g. Leucine-rich repeatcontaining G protein-coupled receptor 5). More strikingly, in contrast to hyperproliferative and hyperangiogenic phenotype of GBM tumors, purified CD133+ GSC, not CD133+ glioblastoma spheres (containing mostly CD133- progeny), express a tumor-suppressor phenotype, which is characterized by the expression of a series of genes associated with an anti-growing, anti-inflammatory, anti-angiogenic, anti-developmental, and migrating phenotype (42). This observation implicate that these GSC may be clinically indolent/quiescent prior to undergoing proliferative cell division, which would produce proliferative and angiogenic GBM effector progeny. Thus, it is possible that some migratory, tumorigenic GBM-stem like clones may use properties of stem cell quiescence to evade firstline treatment and regrow a new tumor at a secondary site after treatment. The molecular properties of GSC also support the view that genes guarding the pools and tumorigenic potential of GSC may not be in the subgroup of genes directly controlling cell proliferation, but in the subgroup regulating cellular quiescence, development, differentiation, and survival. Analysis of the expression of the CD133 in gliomas found that both the proportion of CD133+ cells and their topological organization in clusters were significant prognostic factors for adverse progression-free survival and overall survival (60). Computational comparisons with a collection of published gene expression profiles further reveal that the CD133 gene signature transcriptionally resembles human embryonic stem cells (ES) and GSC, and this signature successfully distinguishes glioblastoma from lower-grade gliomas, and identify an aggressive glioblastoma subtype with excess mutation (61). To date, most anti-cancer therapies aim to eliminate rapidly proliferating tumor cells; thus, the discovery of treatment-resistant, quiescent GSC $(42,58-59,62)$ possessing the enhanced ability to repopulate tumors provides an excellent model to explain our inability to eradicate brain tumors (Figure 5). The identification of genes and pathways and performing pre-clinical validation of gene function in animal experiments may facilitate the discovery and development of innovative treatment protocols for the prevention of post-treatment tumor recurrence through the targeting tumorigenic stem-like GBM cells, which is not targeted in any current anti-cancer treatment.

\section{Essential gene pathways for GSC}

\subsection{In-vitro cultivation of tumorigenic GSC}

It is plausible that the quiescent, migratory, and tumorigenic properties render GSC an excellent candidate for being responsible for post-treatment tumor recurrence. Based on the in vitro and in vivo characterization of GSC, the GSC population is being considered a dynamic fraction of cells highly sensitive to microenvironmental changes or stimulation (e.g. selfrenewal and differentiation). Therefore, identifying both intrinsic and extrinsic signaling pathways by which GSC maintain the tumorigenic capacity to support continuous tumor growth will facilitate the development of novel therapeutic strategies to diminish the recurrence rate of glioblastoma tumors. Current experimental models for the study of GSC in the laboratory have been relatively standardized. In laboratory, GSC are maintained in serumfree media supplemented with epidermal growth factor (EGF) and fibroblast growth factor (FGF) and are able to propagated as a non-adherent or semi-adherent sphere cultures for indefinite passages. More importantly, GSC are capable of clonal self-renewal and proliferative differentiation, thereby allowing populate single cell-derived tumor spheres in cultures. Genome-wide expression microarray analysis of GSC have identified a series of 


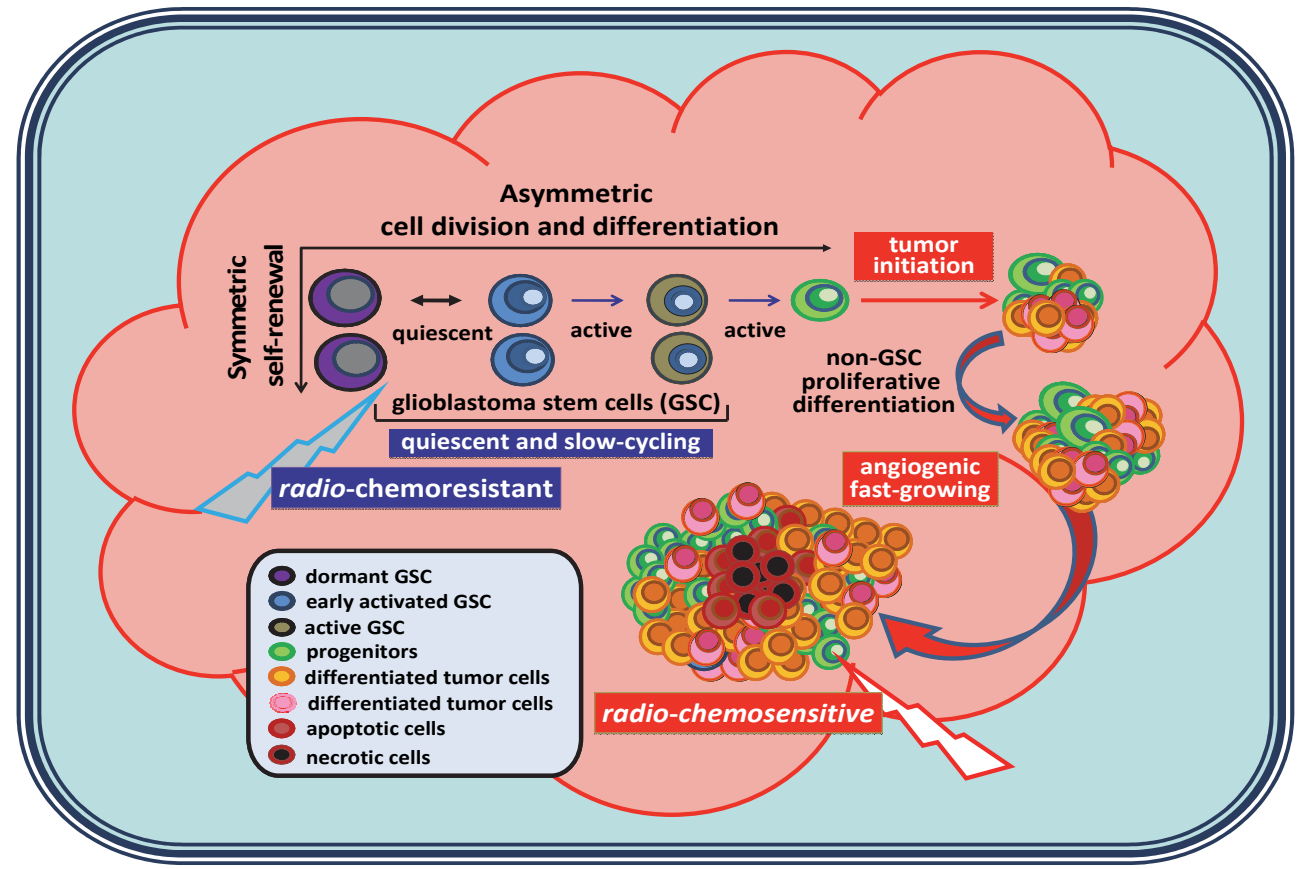

Fig. 5. A theoretical model of glioblastoma stem cells (GSC) contribute to both tumorigenesis and treatment resistance. GSC use both symmetric and asymmetric division to sustain selfrenewal and proliferative differentiation to initiate and maintain a tumor. GSC contain both quiescent and active cell types; the quiescent GSC are slow-cycling, radio-chemoresistant, and capable of unlimited self-renewal, whereas the activated GSC can undergo proliferative differentiaion and initiating a tumor. Progeny of GSC populate a tumor containing a heterogeneous population in different states of differentiation, and are fast-growing, angiogenic, and radio-chemosensitive. Quiescent GSC can escape from radio-chemotherapy and continually replenish tumor cells, leading to sustained tumorigenesis. 
molecular markers associated with adult stem cells (42) and a recent study further showed that GSC express EC markers which can distinguish GSC from NSC (63). GSC possess tumorigenic potential, and by contrast to regular glioblastoma cell lines cultured in serum-containing media, injection of lower number of GSC into mice with severe combined immune deficiency (SCID) is able to initiate and reconstitute GBM tumors in mouse brains, which recapitulate the histopathological features of the patient tumor from which the GSC were derived (42-47). Thus, by using these well-documented in-vitro and in-vivo functional assays of GSC, which can be visualized, assayed, and quantified, investigators have discovered and established several essential gene pathways by which properties and function of GSC can be maintained; in particular, studies using small interfering RNA (siRNA)-mediated loss-of-function phenotype, a particular gene pathway that is involved in maintaining GSC can be identified and verified. Thus, by both in-vitro and in-vivo GSC functional models, several essential genes and signaling pathways for maintaining GSC stemness, tumorigenic capacity, and anti-apoptotic features have been implicated (64, Review).

\subsection{Notch signaling pathway}

Several Notch effector genes, including inhibitor of differentiation 4 (ID4) (65), hairy and enhancer of split 1 (HES1) (66), hairy/enhancer-of-split related with YRPW motif 1 (HEY1) (67) and fatty acid binding protein 7 (FABP7) (68), have been detected in GSC by expression microarray analysis, thereby reflecting the prolonged Notch activation (42). Notch signaling controls numerous cell fate specification events, and it has been implicated in the maintenance of cellular quiescence in many adult stem cell pools by retaining self-renewal potential, suppressing cell differentiation, and protecting them from exhaustion of their proliferative capacity $(66,69-70)$. The Notch signaling network is composed of a family of four Notch receptors (Notch1, Notch2, Notch3, Notch4) and five ligands from the members of the Delta-like (DLL1, DLL3, DLL4) and the Jagged (JAG1, JAG2) families. The signaling permits the gamma secretase-mediated proteolytic release of the Notch intracellular domain (NICD), which translocates into the nucleus and transactivates target genes. Notch signaling regulates NSC differentiation; indication of Notch signaling drives NSC into quiescence, whereas blocking Notch signaling stimulates NSC undergo neurogenesis $(69,71)$. Moreover, Notch signaling is required to convert the hypoxic stimulus into epithelial-mesenchymal transition (EMT), increased motility, and invasiveness (72). Thus, expression of Notch effector genes in GSC implies abrogation of neurogenesis, promoting a migratory phenotype and enhancing glial-fate specification. Importantly, increased expression of FABP7 was found to be associated with regions of GBM tumor infiltration (73), suggesting that Notch activation in GSC may not only maintain the stemness of GSC, but also promote a infiltrating characteristics of brain tumor. Treatment of GBM sphere cultures with gamma-secretase inhibitors (GSIs) can deplete GSC, downregulate stem cell markers (CD133, nestin, BMI1, Olig2), and inhibit self-renewal of GSC in cultures and growth of xenografts (74). The depletion of tumorigenic GSC by Notch signaling blockade was found to occur via reduced cell proliferation and increased cell apoptosis due to decreased levels of phosphorylated AKT and STAT3 (75). In addition, it has be shown that tumor endothelial cells support GSC maintenance, which is in part via Notch signaling (76) and suggested that inhibition of Notch signaling can target GSC via an endothelial cell intermediate. 


\subsection{Hypoxia and hypoxia-inducible factors}

It has been shown that hypoxia-inducible factors (HIFs) regulate tumorigenic capacity of GSC (77-78). When glioblastoma sphere cultures are grown in $1 \%$ oxygen, hypoxic response genes, including HIF-1, HIF-2, lysyl oxidase, and vascular endothelial growth factor (VEGF), are greatly induced, in addidton, both the stem-like side population and CD133+ cells were increased (79). Moreover, GSC respond to hypoxia by enhancing their self-renewal activity and anti-differentiated status (80). Loss of HIF-2a in GSC leads to a significant decrease in both GSC proliferation and self-renewal in cultures, and attenuation of tumorigenic capacity in animals (80). Hypoxia requires Notch signaling for maintaining cells in an undifferentiated state, which occurs by recruiting HIF-1a to the promoters of Notch-responsive target genes (81). The maintenance of GSC by a hypoxic microenvironment via enhancing the activity of other stem cell factors such as Oct4, c-Myc, and Nanog, also partially promotes and stabilizes the stem cell phenotype $(77,82)$. Thus, HIFs might potentially represent a promising target for depleting GSC populations.

\subsection{GLI - Nanog axis}

Nanog and Hedgehog $(\mathrm{HH})$ are two essential regulators of stemness in ES. HH proteins act through the Patched $(\mathrm{Ptc})$ and Smoothened (Smo) and ultimately activates the GLI family of transcription factors. HH-GLI signaling modulates neural progenitor proliferation and survival in the developing neural tube, and controls stem cell behavior in the postnatal and adult brain (83-85). Nanog, a pluripotency homeobox gene, is regulated by HH-GLI signaling via binding of $\mathrm{HH}$ effectors, Gli1 and Gli2, to the Nanog promoter, thus activating Nanog expression (86). A study shows that HH-GLI signaling regulates glioma growth, GSC self-renewal, and tumorigenic capacity, and the blockade of HH-GLI signaling by treatment with cyclopamine depletes GSC (87). Nanog was recently reported to be a novel HH-GLI mediator for expanding CD133+ GSC and promoting glioblastoma growth (88). More importantly, it was found that loss of tumor suppressor p53 activates HH-GLI signaling, thereby contributing to Nanog upregulation and leading to the promoting of GSC stemness. In contrast, the presence of p53 can negatively regulate the activity and level of GLI1, thus downregulating Nanog expression (86, 88-89). Therefore, the inversely reciprocal levels of GLI1 and p53 are consistently maintained in GSC (88). Concurrently, GLI1 upregulates Notch and downregulates bone morphogenetic protein (BMP) signaling, a prodifferentiative action on stem cells (89), implying an essential role of a functional GLI1NANOG-p53-Notch network in maintaining stemness and tumorigenic capacity of GSC. Thus, GLI-Nanog axis provides a potential treatment target for the prevention of GSCmediated tumor recurrence.

\subsection{Transforming growth factor beta (TGF $\beta$ ) signaling}

The TGF- $\beta$ signaling pathway plays an essential role in the regulation of embryonic development, cell proliferation, motility and apoptosis, ECM production and modulation of immune function (90). The TGF- $\beta$ superfamily comprises both growth and differentiation factors including TGF- $\beta$ s, activins, inhibins, and bone morphogenetic proteins (BMPs). TGF $\beta$ signaling by binding to type I and type II receptors on the cell surface. The type II receptor phosphorylates the type I receptor, which propagates the signal by phosphorylating receptor-activated SMAD (R-SMAD) proteins (91) that transduce TGF- $\beta$ 
family signals into a transcriptionally regulated developmental program. A recent study showed that the TGFb/activin signaling pathway is essential for the maintenance of ES cells, which is via binding of SMAD2/3 to the NANOG proximal promoter in human ES (92). Alternatively, TGF $\beta$ signaling can act through Smad-independent pathways, which activate Ras/extracellular signal-regulated kinase (ERK), TGF $\beta$-activated kinase-1/p38 mitogenactivated protein kinase (MAPK)/c-Jun NH2-terminal kinase (TAK1/P38/JNK), phosphatidylinositol 3-kinase(PI3K)/AKT, and signal transducers and activators of transcription 3 (STAT3) (93-94). A study showed that TGF $\beta$ signaling promotes the selfrenewal and tumorigenic capacity of GSC by Smad-dependent induction of leukemia inhibitory factor (LIF) (95). Treatment of GSC with recombinant LIF induced a rapid phosphorylation of STAT3. Thus, TGF $\beta$ signaling promotes GSC self-renewal through the activation of JAK-STAT pathway by the induction of LIF secretion (95). Mice receiving GSC pre-treated with a TGF $\beta$ receptor inhibitor and a JAK inhibitor significantly increased the survival rate compared to the group receiving non-treated GSC, indicating the TGF $\beta$ and JAK-STAT signaling pathways play an essential role for maintaining tumorigenic potential of GSC (95).

A direct mechanistic link of STAT3 activation to GSC growth and self-renewal was further evidenced by two separated studies, demonstrating that knockdown of STAT3 signaling by a short hairpin RNA (shRNA) or inhibitors of STAT3-DNA binding, leads to loss of capacity for tumor sphere formation, induction of cell apoptosis, and a decrease in tumor-initiating capacity in animals (96-97). Therefore, these data suggest that the STAT3 signaling pathway may be a potential target for GSC-directed brain tumor therapy. Since STAT3 signaling is a downstream effector of interleukin-6 (IL-6), blockade of IL-6R alpha or IL-6 expression with shRNAs also suppresses tumor sphere formation capacity and increases survival of mice bearing intracranial glioblastoma xenografts (98). Another related study showed that autocrine TGF-beta signaling maintains stemness of GSC by induction of Sry-related HMGbox 2 (SOX2), one of the key transcription factors required in induced pluripotent stem cells, and this induction was mediated by Sox4, a direct TGF-beta target gene (99). Thus, treatment with inhibitors of TGF-beta signaling drastically deplete GSC by promoting their differentiation, and leads to less lethal potency in intracranial transplantation assay. SOX2 silencing or induction of GSC differentiation by treatment with bone morphogenetic protein 4 led to the loss of self-renewal capacity and tumorigenicity of GSC (62, 100-101), indicating the maintenance of the undifferentiated phenotype is one of the key criteria for retaining tumorigenic capacity of GSC.

\subsection{Epidermal growth factor receptor (EGFR) and down-stream AKT, MEK (mitogen- activated protein kinase/ERK kinase), and ERK 1/2 signaling}

EGFR is commonly amplified and/or mutated in high-grade gliomas. A study showed that EGFR signaling pathway is involved in the maintenance of GSC and is required for gliomagenesis (102). Treatment of GSC with tyrosine kinase inhibitors of EGFR signaling suppresses GSC self-renewal and induces cell apoptosis through the inhibition of phosphorylation of EGFR, AKT kinase, and ERK 1/2 (103-104). Likewise, GSC display preferential sensitivity to Akt inhibition relative to matched non-GSC cells and inhibition of Akt activity in GSC increased the survival of animal bearing human glioma xenografts (105). Similar results are also demonstrated by a targeted inactivation of MEK/ERK signaling, which led to the reduction of sphere-forming capacity of GSC accompanied by 
their differentiation into neuronal and glial lineages (106). Moreover, combinational blockade of both MEK/ERK and PI3K/mTOR pathways suppressed the tumorigenic capacity of GSC more effectively than blockade of either alone (107). These results therefore indicate that the EGF/EGFR signaling and its downstream effector activation are essential for maintaining GSC, suggesting a potential molecular pathway target for depletion of GSC.

\section{7 c-Myc}

c-Myc belongs to a family of transcription factors containing basic, helix-loop-helix, and leucine zipper domains and it is an essential factor for normal embryonic development (108). c-Myc is an oncogenic transcription factor commonly overexpressed in a variety of human cancers. In contrast, c-Myc gene inactivation triggers telomere-independent senescence mediated by the cyclin-dependent kinase inhibitor p16INK4a, which is regulated by the polycomb group repressor Bmi-1, a direct transcriptional target of c-Myc (109). Highlevel of c-Myc expression was found in GSC relative to non-stem glioma cells, and knockdown of c-Myc in GSC induces cell apoptosis and leads to the loss of tumorigenic capacity (110). A recent study further showed that HIF-2a promotes GSC self-renewal and stemness properties via enhancing the expression of c-Myc (82), and inactivation of PTEN and p53 can also lead to the increased expression of c-Myc and promotion of stemness, selfrenewal and the tumorigenic capacity of GSC (111). These data suggest that the c-Myc signaling pathway is required for maintaining the self-renewal capability and tumorigenic potential of GSC, and therefore may serve as a potential signaling pathway target for a GSC -directed brain cancer therapy.

\subsection{L1 cell adhesion molecule (L1CAM), Olig2, Bmi-1, integrin a6, and A20}

L1CAM is a cell adhesion molecule plays an important role in nervous system development, including neuronal migration and differentiation (112). L1CAM expression was found to be preferentially higher in GSC compared to normal neural progenitors, and knockdown of L1CAM expression via shRNA interference can lead to the loss of sphereforming capacity, induced cell apoptosis, and suppressed tumor growth (113). The induction of GSC apoptosis by decreasing the expression of L1CAM is suggested due to the decreased expression of the basic helix-loop-helix transcription factor Olig2 and the increased expression of the p21WAF1/CIP1 tumor suppressor (113). Correspondingly, it has been shown that an Olig2-regulated lineage-restricted pathway is critical for proliferation and maintenance of tumorigenic GSC through the suppression of p21WAF1/CIP1 (114).

Bmi1 plays an essential part in the self-renewal of hematopoietic stem cells (HSC) and NSC (115-117). Bmi1 is part of the Polycomb group gene family and a member of polycombrepressing complex 1 (PRC1), which is required to maintain the transcriptionally repressive state of many genes by chromatin remodeling and histone modification (118-119). It has been shown that Bmi-1 is highly expressed in CD133+ GSC and Bmi-1 knockdown resulted in inhibition of self-renewal capacity and induction of both cell apoptosis and cell differentiation, as well as loss of tumorigenic capacity (120). Similarly, disruption of EZH2, the main component of PRC2, robustly impairs self-renewal and tumorigenic capacity of GSC (121). This data thus suggest that PcG proteins are required for maintaining stemness, survival, and tumorigenic capacity of GSC. 
Integrins are one of the major families of cell adhesion receptors that cells use to both bind to and respond to the ECM (122). Specifically, integrin a6 subunit is critical for the early development of the nervous system and has been shown to play a role in neuronal migration, neurite outgrowth, and axon guidance during olfactory development (123). A recent study showed that GSC highly express integrin a6 and their interaction with laminin on endothelial cells directly regulates the tumorigenic capacity of GSC (124). Targeting integrin a6 in GSCs inhibits self-renewal, proliferation, and tumor formation capacity (124), indicating integrin a6 is an essential factor for maintaining GSC and can be potentially used as a cellular target for depletion of GSCs.

Tumor necrosis factor, alpha-induced protein 3 (TNFAIP3) or A20, a zinc finger protein, is an NF-kB-inducible gene. A20 can protect the cells from TNF-induced apoptosis by disrupting the recruitment of the death domain signaling molecules TRADD and RIP to the receptor signaling complex (125). A novel anti-apoptotic mechanism of A20 was recently reported and showed that A20 blocks TNF-induced apoptosis through suppression of c-jun N-terminal kinase (JNK) by targeting apoptosis signal-regulating kinase1 (ASK1) (126). A20 was overexpressed in clinical glioma tissue samples and correlates to clinical staging (127). A recent study showed that GSC overexpress A20, relative to non-stem glioma cells, and this protects GSC from cell death (128). Inhibiting A20 expression by shRNA (shRNA) decreased GSC growth and survival through mechanisms associated with decreased cell-cycle progression and decreased phosphorylation of NF-kappaB p65(RelA). By contrast, elevated levels of A20 in GSCs contributed to apoptotic resistance and were less susceptible to TNFalpha-induced cell death than matched non-stem glioma cells. A20 knockdown reduced the self-renewal ability of these cells and decreased tumorigenic potential of GSCs, thereby resulting in increased survival of mice bearing human glioma xenografts. Thus, A20 contributes to glioma maintenance likely through anti-apoptotic effects on GSC.

\section{Gene pathways underlying the radio-chemoresistant phenotype of GSC}

Concurrent TMZ and RT followed by adjuvant TMZ is standard for patients with newly diagnosed glioblastoma based on a large randomized phase III trial that showed survival benefit (129-130). Studies further showed that patients whose tumor had a methylated promoter for the gene encoding O6-methylguanine-DNA methyltransferase (MGMT), a DNA repair protein, were more likely to benefit from the addition of $\operatorname{TMZ}(22,130)$. Although the survival advantage of combined treatment lasts up to 5 years of follow-up, most patients successfully treated with combined therapy eventually had tumor recurrence and died (130). A significant increase in MGMT expression was found in first recurrence after treatment with RT plus TMZ, indicating either selection of MGMTexpressing cells or induction of the MGMT gene by TMZ (131). Molecular analysis of glioblastoma tumors resistance to the concomitant radio-chemotherapy with TMZ had identified a self-renewal signature dominated by homeobox (HOX) genes, which are comprised of CD133 (132). Of note, tumors with the enhanced expression of HOX genes, high EGFR expression, plus unmethylated MGMT were associated with short survival (132), implicating the association of stem-cell phenotype and radiochemoresistance. It is plausible that the quiescent stem cell nature adopted by GSC may explain the considerable resistance to chemotherapeutic agents (133-136). Moreover, quiescent cells show greater repair capacities than proliferative cells $(58,135)$, suggesting that slow- 
cycling GSC may play a key role in the acquired or constitutive resistance to radiochemotherapy (137).

\subsection{Activation of checkpoint proteins}

A study indicated a potential role of DNA damage checkpoint protein, Chk1 and Chk2 kinases in the radioresistant phenotype of CSC (58). Particularly, CD133+ GSC isolated from glioblastoma tumors preferentially activated $\mathrm{Chk} 1 / 2$ kinases, and repaired radiationinduced DNA damage more effectively than CD133- non-GSC cells (58), indicting stem-like glioblastoma cell population within tumor mass are likely responsible for the treatment resistance. This notion was further supported by the demonstrating that the radioresistant phenotype of GSC can be reversed by the treatment with a specific inhibitor of the Chk1 and Chk2 checkpoint kinases (58).

\subsection{Evasion of cell-death pathway}

Evidently, GSC exhibit enhanced chemoresistance to anticancer drugs (59, 138-139). The expression of ATP-binding cassette transporter ABCG2 in a tumorigenic stem-like side population (SP) distinguish them from the non-stem-like cells (138), suggesting a potential mechanism underlying chemoresistance in CSCs. Several anti-apoptotic genes (e.g. BCL-2, BCL2L1a, and MCL1) were also found to be at higher expression levels in TMZ resistantGSC clones than those in differentiated cell lines (140). Likewise, CD133+ GSC were characterized by the enhanced expression of multidrug resistance 1 (MDR1) compared to CD133- non-stem cells (139). Moreover, the radio-resistance of GSC could be alleviated by treatment with an XIAP inhibitor (141). Thus, the radio-chemoresistance of GSC may be linked to the activation of the DNA damage checkpoint response, MGMT-mediated DNA repair, expression of both drug efflux transporters and anti-apoptotic factors, or abnormalities of cell-death pathways $(59,132,138,141)$.

\subsection{Constitutively active Notch and PI3K/Akt signaling}

Notch signaling promotes radioresistance of GSC by upregulating PI3K/AKT pathway signaling and increasing the expression levels of myeloid cell leukemia-1(MCL1), an antiapoptotic member of Bcl-2 family. The knockdown of Notch1 or Notch2 signaling in GSC sensitizes GSC to radiation treatment and impairs tumorigenic capacity (142), indicating a critical role of Notch/PI3K/AKT signaling in radioresistance of GSC. Moreover, addition of GSIs enhances TMZ treatment of human gliomas by inhibiting neurosphere repopulation and xenograft recurrence (143), pointing out the essential role of Notch pathway in chemoprotection of GSC.

\subsection{Bmi-1-mediated DNA damage response}

Bmi-1 plays important roles in histone $\mathrm{H} 2 \mathrm{~A}$ ubiquitination and HOX gene silencing, and is a potent negative regulator of the Ink4a/Arf locus, which encodes the cell cycle regulators and tumor suppressor p16Ink4a and p19Arf genes $(144,145)$. BMI1 was enriched at the chromatin after irradiation and colocalized with ataxia-telangiectasia mutated (ATM) kinase and the histone gammaH2AX, an important DNA double strand break (DSB) repair pathway (144). A recent study showed that Bmi-1 preferentially copurified with nonhomologous end joining (NHEJ) proteins in CD133+ GSC, suggesting that Bmi-1 confers 
radioresistance to GSC may through the recruitment of DNA damage response machinery (145).

\subsection{Insulin-like growth factor binding protein 2 (IGFBP2)}

IGFBP-2 is a member of a family of six highly conserved IGFBPs that are carriers for the IGFs. The heparin-binding domain (HBD) of IGFBP2 has anabolic activity by activating IGFI/Akt and $\beta$-catenin signaling pathways (146). IGFBP2 is known to be overexpressed in a majority of glioblastoma tumors, and its expression is inversely correlated to glioblastoma patient survival $(40,147)$. IGFBP2 enhances tumor invasion by upregulating matrix metalloproteinase-2 and CD24 $(148,149)$. Recent studies indicated that IGFBP2 is overexpressed in GSC $(42,150)$ and autocrine IGFBP2 is required for self-renewal and expansion of GSC (150). The knockdown of IGFBP2 expression downregulated the expression of stemness-associated gene and reduced AKT activation, and treatment with an IGFBP2 neutralizing antibody sensitized GSC to irradiation and multiple anti-neoplastic agents (150). As anticipated, recombinant IGFPB2 substantiated AKT signaling-mediated GSC viability that could be blocked by treatment with PI3K/Akt inhibitors, suggesting that IGFBP2 contributes to anti-apoptotic features of GSC.

\section{Final remarks}

The isolation and characterization of GSC have not only significantly changed the biological view of tumors, but has also impacted the design of effective therapies, as radiochemoresistant, stem-like, tumorigenic glioblastoma cells may continue seeding the new tumor, despite local treatment to the tumor mass. Currently, the GSC hypothesis and model are not fully established. However, the accumulated preclinical data generated and established from both in-vitro and in-vivo GSC model systems will certainly facilitate the exploration of new concepts in tumor biology, tumor relapse and the design of potentially more effective treatment protocols that can specifically target GSC with radiochemoresistant features. Meanwhile, since CSC share many signaling pathways with normal stem cells, exploring differences between normal and tumor stem cells may reveal novel, tumor-specific molecular targets for a safe therapy for brain cancer. Moreover, identifying the extrinsic cues and effects from their niche on GSC is also crucial as they may provide vital signaling to modulate GSC physiology and pathology (151-152). The cure for cancer requires eliminating both GSC and non-GSC populations; thus, it is important to design preclinical studies and clinical trials which evaluate the synergistic benefits of incorporating GSC-targeted therapies into conventional cancer treatments. Based on the molecular pathways of gliblastoma and GSC discussed in this chapter, I designed a therapeutic model for targeting both fast-growing, hyper-angiogenic glioblastoma tumor cells and slowcycling, quiescent, anti-apoptotic GSC; the model theoretically and ideally, can prevent posttreatment tumor recurrence (Figure 6).

\section{Acknowledgments}

I thank Jonathan Tso, for the critical review of this chapter. This work was supported by the grants from American Cancer Society (RSG-07-109-01-CCE), National Cancer Institute (1 R21 CA140912-01), National Institute of Health (1DP2OD006444-01), and The Bradley Zankel Foundation to C-L T. 


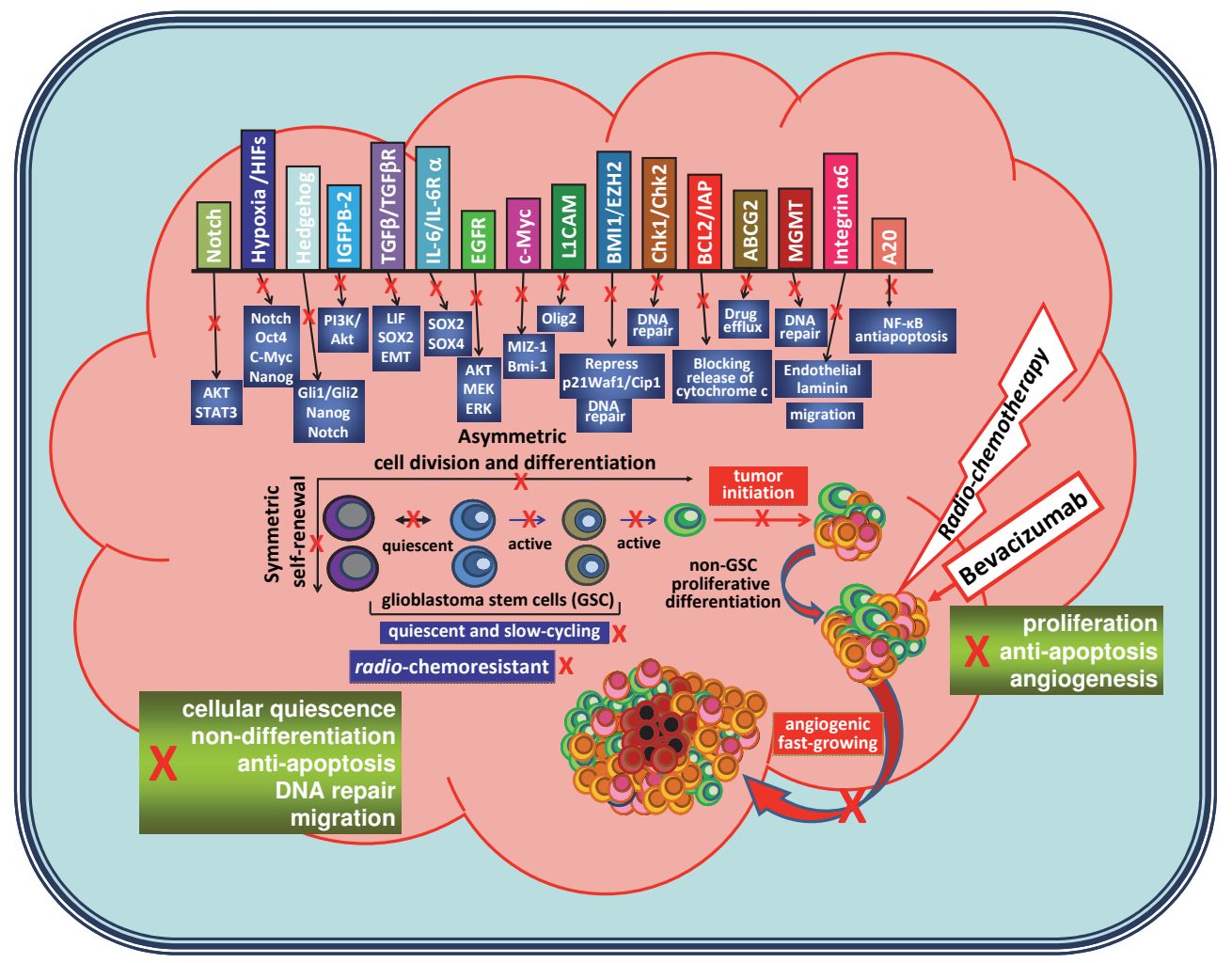

Fig. 6. A model of glioblastoma stem cell (GSC)-targeted brain cancer therapy. GSC utilize multiple stem cell associated-signaling pathways to achieve a radio-chemoresistant phenotype that sustains tumorigenesis. Essential gene pathways as indicated have been determined to be required for maintaining stemness properties, tumorigenic capacity and a radio-chemoresistant phenotype of GSC. Radiochemoresistance may be accomplished via collaboration of constitutive activation of the DNA damage checkpoint response and PI3KAkt signaling pathway, high expression of both anti-apoptotic proteins and drug efflux transporters, and evasion of both differentiation and irreversible cell cycle arrest (cellular quiescence). In order to eradicate a tumor and prevent post-treatment tumor recurrence, a therapeutic strategy that target essential gene pathways for maintaining GSC must be developed to be fully integrated into radio-chemotherapy and anti-angiogenic therapy in order to target both quiescent GSC and fast-growing, angiogenic non-GSC populations. 


\section{References}

[1] Prat DJ, Van Meir EG. Vaso-occlusive and prothrombotic mechanisms associated with tumor hypoxia, necrosis, and accelerated growth in glioblastoma (review). Lab Invest 2004; 84: 397-405.

[2] Kleihues P, Ohgaki H. Primary and secondary glioblastomas: from concept to clinical diagnosis. Neuro-oncol. 1:44-51, 1999. Review.

[3] Maruno M, Ninomiya H, Ghulam Muhammad AK, Hirata M, Kato A, Yoshimine T. Whole-genome analysis of human astrocytic tumors by comparative genomic hybridization. Brain Tumor Pathol. 17:21-7, 2000.

[4] Brat DJ, Castellano-Sanchez A, Kaur B, Van Meir EG. Genetic and biologic progression in astrocytomas and their relation to angiogenic dysregulation. Adv Anat Pathol. 9:2436, 2002. Review.

[5] Schmidt MC, Antweiler S, Urban N, Mueller W, Kuklik A, Meyer-Puttlitz B, Wiestler OD, Louis DN, Fimmers R, von Deimling A. Impact of genotype and morphology on the prognosis of glioblastoma. J Neuropathol Exp Neurol. 61:321- 328, 2002.

[6] Watanabe K, Tachibana O, Sata K, Yonekawa Y, Kleihues P, Ohgaki H. Overexpression of the EGF receptor and p53 mutations are mutually exclusive in the evolution of primary and secondary glioblastomas. Brain Pathol. 6:217-223, 1996.

[7] Ohgaki H, Kleihues P. Genetic pathways to primary and secondary glioblastoma. Am J Pathol 170:1445-1453, 2007.

[8] Henson JW, Schnitker BL, Correa KM, von Diemling A, Fassbender F, Xu HJ, Benedict WF, Yandell DW, Louis DN. The retinoblastoma gene is involved in malignant progression of astrocytomas. Ann. Neurol. 36: 714-721, 1994.

[9] Schwechheimer K, Huang S, Cavenee WK. EGFR gene amplification- rearrangement in human glioblastomas. Int. J. Cancer, 62: 145-148, 1995.

[10] Wong AJ, Ruppert JM, Bigner SH, Grzeschik CH, Humphrey PA, Bigner DS, Vogelstein B. Structural alterations of the epidermal growth factor receptor gene in human gliomas. Proc. Natl. Acad. Sci. USA, 89: 2965-2969, 1992.

[11] Ekstrand A J, Sugawa N, James CD, Collins VP. Amplified and rearranged epidermal growth factor receptor genes in human glioblastomas reveal deletions of sequences encoding portions of the N- and/or C-terminal tails. Proc. Natl. Acad. Sci. USA, 89: 4309-4313, 1992.

[12] Chu CT, Everiss KD, Wikstrand CJ, Batra SK, Kung HJ, Bigner DD. Receptor dimerization is not a factor in the signalling activity of a transforming variant epidermal growth factor receptor (EGFRvIII). Biochem. J. 324: 855-861, 1997.

[13] Ekstrand AJ, Longo N, Hamid ML, Olson JJ, Liu L, Collins VP, James CD. Functional characterization of an EGF receptor with a truncated extracellular 19 domain expressed in glioblastomas with EGFR gene amplification. Oncogene. 9: 2313-2320, 1994

[14] Wong AJ, Ruppert JM, Bigner SH, Grzeschik CH, Humphrey PA, Bigner DS, Vogelstein B. Structural alterations of the epidermal growth factor receptor gene in human gliomas. Proc. Natl. Acad. Sci. USA, 89: 2965-2969, 1992. 
[15] Frederick L, Wang XY, Eley G, James CD. Diversity and frequency of epidermal growth factor receptor mutations in human glioblastomas. Cancer Res. 60:13831387, 2000.

[16] Shieh SY, Ikeda M, Taya Y, Prives C. DNA damage-induced phosphorylation of p53 alleviates inhibition by MDM2. Cell. 91: 325-334, 1997.

[17] Arslantas A, Artan S, Oner U, Müslümanoğlu H, Durmaz R, Cosan E, Atasoy MA, Başaran N, Tel E. The importance of genomic copy number changes in the prognosis of glioblastoma multiforme. Neurosurg Rev. 27(1): 58-64, 2004.

[18] Furnari FB, Fenton T, Bachoo RM, Mukasa A, Stommel JM, Stegh A, Hahn WC, Ligon KL, Louis DN, Brennan C, Chin L, DePinho RA, Cavenee WK. Malignant astrocytic glioma: genetics, biology, and paths to treatment. Genes Dev. 21:2683-2710, 2007.

[19] Fulci G, Labuhn M, Maier D, Lachat Y, Hausmann O, Hegi ME, Janzer RC, Merlo A, Van Meir EG.p53 gene mutation and ink4a-arf deletion appear to be two mutually exclusive events in human glioblastoma. Oncogene. 19:3816-3822, 2000.

[20] Nakamura M, Yang F, Fujisawa H, Yonekawa Y, Kleihues P, Ohgaki H. Loss of heterozygosity on chromosome 19 in secondary glioblastomas. J Neuropathol Exp Neurol. 59:539-543, 2000.

[21] Ino Y, Zlatescu MC, Sasaki H, Macdonald DR, Stemmer-Rachamimov AO, Jhung S, Ramsay DA, von Deimling A, Louis DN, Cairncross JG. Long survival 16 and therapeutic responses in patients with histologically disparate high-grade gliomas demonstrating chromosome 1p loss. J Neurosurg. 92:983-990, 2000.

[22] Hegi ME, Diserens AC, Gorlia T, Hamou MF, de Tribolet N, Weller M, Kros JM, Hainfellner JA, Mason W, Mariani L, Bromberg JE, Hau P, Mirimanoff RO, Cairncross JG, Janzer RC, Stupp R.MGMT gene silencing and benefit from temozolomide in glioblastoma. N Engl J Med. 352(10):997-1003, 2005.

[23] Maurer GD, Tritschler I, Adams B, Tabatabai G, Wick W, Stupp R, Weller M. Cilengitide modulates attachment and viability of human glioma cells, but not sensitivity to irradiation or temozolomide in vitro. Neuro Oncol. 11(6):747-756, 2009.

[24] Brandes AA, Franceschi E, Tosoni A, Benevento F, Scopece L, Mazzocchi V, Bacci A, Agati R, Calbucci F, Ermani M. Temozolomide concomitant and adjuvant to radiotherapy in elderly patients with glioblastoma: correlation with MGMT promoter methylation status.Cancer. 115(15):3512-3518, 2009.

[25] Parsons DW, Jones S, Zhang X, Lin JC, Leary RJ, Angenendt P, Mankoo P, Carter H, Siu IM, Gallia GL, Olivi A, McLendon R, Rasheed BA, Keir S, Nikolskaya T, Nikolsky Y, Busam DA, Tekleab H, Diaz LA Jr, Hartigan J, Smith DR, Strausberg RL, Marie SK, Shinjo SM, Yan H, Riggins GJ, Bigner DD, Karchin R, Papadopoulos N, Parmigiani G, Vogelstein B, Velculescu VE, Kinzler KW. An integrated genomic analysis of human glioblastoma multiforme.Science. 321(5897):1807-1812, 2008.

[26] Ichimura K, Pearson DM, Kocialkowski S, Bäcklund LM, Chan R, Jones DT, Collins VP. IDH1 mutations are present in the majority of common adult gliomas but rare in primary glioblastomas.Neuro Oncol. 11(4):341-347, 2009.

[27] Yan H, Parsons DW, Jin G, McLendon R, Rasheed BA, Yuan W, Kos I, Batinic-Haberle I, Jones S, Riggins GJ, Friedman H, Friedman A, Reardon D, Herndon J, Kinzler 
KW, Velculescu VE, Vogelstein B, Bigner DD. IDH1 and IDH2 mutations in gliomas.N Engl J Med. 360(8):765-773, 2009.

[28] Nobusawa S, Watanabe T, Kleihues P, Ohgaki H. IDH1 mutations as molecular signature and predictive factor of secondary glioblastomas. Clin Cancer Res. 15(19):6002-6007, 2009.

[29] Hartmann C, Hentschel B, Wick W, Capper D, Felsberg J, Simon M, Westphal M, Schackert G, Meyermann R, Pietsch T, Reifenberger G, Weller M, Loeffler M, von Deimling A. Patients with IDH1 wild type anaplastic astrocytomas exhibit worse prognosis than IDH1-mutated glioblastomas, and IDH1 mutation status accounts for the unfavorable prognostic effect of higher age: implications for classification of gliomas. Acta Neuropathol. 120(6):707-718, 2010.

[30] Szallasi Z. Bioinformatics. Gene expression patterns and cancer. Nat Biotechnol. 16:1292-1293, 1998.

[31] Loging WT, Lal A, Siu IM, Loney TL, Wikstrand CJ, Marra MA, Prange C, Bigner DD, Strausberg RL, Riggins GJ. Identifying potential tumor markers and antigens by database mining and rapid expression screening. Genome Res. 10:1393-1402, 2000.

[32] Liotta L, Petricoin E. Molecular profiling of human cancer. Nat Rev Genet. 1:48-56, 2000.

[33] Bullinger L, Dohner K, Bair E, Frohling S, Schlenk RF, Tibshirani R, Dohner H, Pollack JR.Use of gene-expression profiling to identify prognostic subclasses in adult acute myeloid leukemia. N Engl J Med. 350:1605-1616, 2004.

[34] Cairncross JG, Ueki K, Zlatescu MC, Lisle DK, Finkelstein DM, Hammond RR, Silver JS, Stark PC, Macdonald DR, Ino Y, Ramsay DA, Louis DN. Specific genetic predictors of chemotherapeutic response and survival in patients with anaplastic oligodendrogliomas. J Natl Cancer Inst. 90:1473-1479, 1998.

[35] Nutt CL, Mani DR, Betensky RA, Tamayo P, Cairncross JG, Ladd C, Pohl U, Hartmann C, McLaughlin ME, Batchelor TT, Black PM, von Deimling A, Pomeroy SL, Golub TR, Louis DN. Gene expression-based classification of malignant gliomas correlates better with survival than histological classification. Cancer Res. 63:1602-1607, 2003.

[36] Albertson DG, Collins C, McCormick F, Gray JW. Chromosome aberrations in solid tumors. Nat Genet. 34:369-376, 2003.

[37] Zhu Y, Parada LF. The molecular and genetic basis of neurological tumours. Nat Rev Cancer. 2:616-626, 2002.

[38] Phillips HS, Kharbanda S, Chen R, Forrest WF, Soriano RH, Wu TD, Misra A, Nigro JM, Colman H, Soroceanu L, Williams PM, Modrusan Z, Feuerstein BG, Aldape K.Molecular subclasses of high-grade glioma predict prognosis, delineate a pattern of disease progression, and resemble stages in neurogenesis. Cancer Cell. 9(3):157173, 2006.

[39] Freije WA, Castro-Vargas FE, Fang Z, et al. Gene expression profiling of gliomas strongly predicts survival. Cancer Res. 64: 6503-6510, 2004.

[40] Tso CL, Freije WA, Day A, Chen Z, Merriman B, Perlina A, Lee Y, Dia EQ, Yoshimoto K, Mischel PS, Liau LM, Cloughesy TF, Nelson SF.Distinct transcription profiles of primary and secondary glioblastoma subgroups. Cancer Res. 66(1):159-67, 2006. 
[41] Tso CL, Shintaku P, Chen J, Liu Q, Liu J, Chen Z, Yoshimoto K, Mischel PS, Cloughesy TF, Liau LM, Nelson SF.Primary glioblastomas express mesenchymal stem-like properties. Mol Cancer Res. 4(9):607-619, 2006.

[42] Liu Q, Nguyen DH, Dong Q, Shitaku P, Chung K, Liu OY, Tso JL, Liu JY, Konkankit V, Cloughesy TF, Mischel PS, Lane TF, Liau LM, Nelson SF, Tso CL.Molecular properties of $\mathrm{CD} 133+$ glioblastoma stem cells derived from treatment-refractory recurrent brain tumors. J Neurooncol. 94(1):1-19, 2009.

[43] Yuan X, Curtin J, Xiong Y, Liu G, Waschsmann-Hogiu S, Farkas DL, Black KL, Yu JS. Isolation of cancer stem cells from adult glioblastoma multiforme. Oncogene 23:9392-9400, 2004.

[44] Hemmati HD, Nakano I, Lazareff JA, Masterman-Smith M, Geschwind DH, BronnerFraser M, Kornblum HI. Cancerous stem cells can arise from pediatric brain tumors. Proc Natl Acad Sci USA. 100:15178-15183, 2003.

[45] Singh SK, Hawkins C, Clarke ID, Squire JA, Bayani J, Hide T, Henkelman RM, Cusimano MD, Dirks PB.Identification of human brain tumour initiating cells. Nature. 432:396-401, 2004.

[46] Galli R, Binda E, Orfanelli U. Isolation and characterization of tumorigenic, stem-like neural precursors from human glioblastoma. Cancer Res. 64:7011-7021, 2004.

[47] Wang J, Sakariassen PØ, Tsinkalovsky O, Immervoll H, Bøe SO, Svendsen A, Prestegarden L, Røsland G, Thorsen F, Stuhr L, Molven A, Bjerkvig R, Enger PØ.CD133 negative glioma cells form tumors in nude rats and give rise to CD133 positive cells. Int J Cancer. 122(4):761-8, 2008.

[48] Beier D, Hau P, Proescholdt M, Lohmeier A, Wischhusen J, Oefner PJ, Aigner L, Brawanski A, Bogdahn U, Beier CP. Cancer Res. 67: 4010-4015, 2007.

[49] Günther HS, Schmidt NO, Phillips HS, Kemming D, Kharbanda S, Soriano R, Modrusan Z, Meissner H, Westphal M, Lamszus K. Oncogene. 27: 2897-2909, 2008.

[50] Son MJ, Woolard K, Nam DH, Lee J, Fine HA. SSEA-1 is an enrichment marker for tumor-initiating cells in human glioblastoma. Cell Stem Cell. 4:440-452, 2009.

[51] Tchoghandjian A, Baeza N, Colin C, Cayre M, Metellus P, Beclin C, Ouafik L, FigarellaBranger D. A2B5 cells from human glioblastoma have cancer stem cell properties. Brain Pathol. 20:211-221, 2010.

[52] Bonnet D, Dick JE.Human acute myeloid leukemia is organized as a hierarchy that originates from a primitive hematopoietic cell. Nat Med. 3(7):730-737, 1997.

[53] Vermeulen L, Todaro M, de Sousa Mello F, Sprick MR, Kemper K, Perez Alea M, Richel DJ, Stassi G, Medema JP. Single-cell cloning of colon cancer stem cells reveals a multi-lineage differentiation capacity. Proc Natl Acad Sci U S A. 105(36):13427-32, 2008.

[54] Dalerba P, Cho RW, Clarke MF. Cancer stem cells: models and concepts. Annu Rev Med. 58:267-284, 2007.

[55] Beachy PA, Karhadkar SS, Berman DM. (2004) Tissue repair and stem cell renewal in carcinogenesis. Nature. 432:324-331, 2004.

[56] Zhang QB, Ji XY, Huang Q, Dong J, Zhu YD, Lan Q. Differentiation profile of brain tumor stem cells: a comparative study with neural stem cells. Cell Res. 16:909-915, 2006. 
[57] Clarke MF, Dick JE, Dirks PB, Eaves CJ, Jamieson CH, Jones DL, Visvader J, Weissman IL, Wahl GM. Cancer stem cells-perspectives on current status and future directions: AACR workshop on cancer stem cells. Cancer Res. 66:9339-9344, 2006.

[58] Bao S, Wu Q, McLendon RE, Hao Y, Shi Q, Hjelmeland AB, Dewhirst MW, Bigner DD, Rich JN.Glioma stem cells promote radioresistance by preferential activation of the DNA damage response. Nature. 444: 756-760, 2006.

[59] Eramo A, Ricci-Vitiani L, Zeuner A, Pallini R, Lotti F, Sette G, Pilozzi E, Larocca LM, Peschle C, De Maria R.Chemotherapy resistance of glioblastoma stem cells. Cell Death Differ. 13(7):1238-1241, 2006.

[60] Zeppernick F, Ahmadi R, Campos B, Dictus C, Helmke BM, Becker N, Lichter P, Unterberg A, Radlwimmer B, Herold-Mende CC.Stem cell marker CD133 affects clinical outcome in glioma patients. Clin Cancer Res. 14(1):123-129, 2008.

[61] Yan X, Ma L, Yi D, Yoon JG, Diercks A, Foltz G, Price ND, Hood LE, Tian Q. A CD133related gene expression signature identifies an aggressive glioblastoma subtype with excessive mutations. Proc Natl Acad Sci U S A. 108(4):1591-1596, 2011.

[62] Piccirillo SG, Reynolds BA, Zanetti N, Lamorte G, Binda E, Broggi G, Brem H, Olivi A, Dimeco F, Vescovi AL. Bone morphogenetic proteins inhibit the tumorigenic potential of human brain tumour-initiating cells. Nature. 444(7120):761-765, 2006.

[63] Field M, Alvarez A, Bushnev S, Sugaya K. Embryonic stem cell markers distinguishing cancer stem cells from normal human neuronal stem cell populations in malignant glioma patients. Clin Neurosurg. 57:151-159, 2010.

[64] Yamada K, Tso J, Ye F, Choe J, Liu Y, Liau LM, Tso CL. Essential Gene Pathways for Glioblastoma Stem Cells: Clinical Implications for Prevention of Tumor Recurrence. Cancers. 3(2):1975-1995, 2011. doi: 10.3390/cancers3021975

[65] Jeon HM, Jin X, Lee JS, Oh SY, Sohn YW, Park HJ, Joo KM, Park WY, Nam DH, DePinho RA, Chin L, Kim H. Inhibitor of differentiation 4 drives brain tumorinitiating cell genesis through cyclin E and notch signaling. Genes Dev. 22:20282033, 2008.

[66] Sang L, Coller HA, Roberts JM. Control of the reversibility of cellular quiescence by the transcriptional repressor HES1. Science. 321:1095-1100, 2008.

[67] Sakamoto M, Hirata H, Ohtsuka T, Bessho Y, Kageyama R. The basic helix-loop-helix genes Hesr1/Hey1 and Hesr2/Hey2 regulate maintenance of neural precursor cells in the brain. J Biol Chem. 278:44808-44815, 2003.

[68] Liang Y, Bollen AW, Nicholas MK, Gupta N. Id4 and FABP7 are preferentially expressed in cells with astrocytic features in oligodendrogliomas and oligoastrocytomas. BMC Clin Pathol. 5:6, 2005.

[69] Chapouton P, Skupien P, Hesl B, Coolen M, Moore JC, Madelaine R, Kremmer E, FausKessler T, Blader P, Lawson ND, Bally-Cuif L. Notch activity levels control the balance between quiescence and recruitment of adult neural stem cells. J Neurosci. 30:7961-7974, 2010.

[70] Bray SJ. Notch signalling: a simple pathway becomes complex. Nat Rev Mol Cell Biol. 7:678-689, 2006. 
[71] Mizutani K, Yoon K, Dang L, Tokunaga A, Gaiano N. Differential Notch signalling distinguishes neural stem cells from intermediate progenitors. Nature. 449:351-355, 2007.

[72] Sahlgren C, Gustafsson MV, Jin S, Poellinger L, Lendahl U. Notch signaling mediates hypoxia-induced tumor cell migration and invasion. Proc Natl Acad Sci U S A. 105(17):6392-6397, 2008.

[73] Kaloshi G, Mokhtari K, Carpentier C, Taillibert S, Lejeune J, Marie Y, Delattre JY, Godbout R, Sanson M. FABP7 expression in glioblastomas: relation to prognosis, invasion and EGFR status. J Neurooncol. 84:245-248, 2007.

[74] Anthony TE, Mason HA, Gridley T, Fishell G, Heintz N. Brain lipid-binding protein is a direct target of Notch signaling in radial glial cells. Genes Dev. 19:1028-1033, 2005.

[75] Fan X, Khaki L, Zhu TS, Soules ME, Talsma CE, Gul N, Koh C, Zhang J, Li YM, Maciaczyk J, Nikkhah G, Dimeco F, Piccirillo S, Vescovi AL, Eberhart CG. NOTCH pathway blockade depletes CD133-positive glioblastoma cells and inhibits growth of tumor neurospheres and xenografts. Stem Cells. 28:5-16, 2010.

[76] Hovinga KE, Shimizu F, Wang R, Panagiotakos G, Van Der Heijden M, Moayedpardazi H, Correia AS, Soulet D, Major T, Menon J, Tabar V. Inhibition of notch signaling in glioblastoma targets cancer stem cells via an endothelial cell intermediate. Stem Cells. 28:1019-1029, 2010.

[77] Li Z, Bao S, Wu Q, Wang H, Eyler C, Sathornsumetee S, Shi Q, Cao Y, Lathia J, McLendon RE, Hjelmeland AB, Rich JN. Hypoxia-inducible factors regulate tumorigenic capacity of glioma stem cells. Cancer Cell. 15(6):501-513, 2009.

[78] Seidel S, Garvalov BK, Wirta V, von Stechow L, Schänzer A, Meletis K, Wolter M, Sommerlad D, Henze AT, Nistér M, Reifenberger G, Lundeberg J, Frisén J, Acker T. A hypoxic niche regulates glioblastoma stem cells through hypoxia inducible factor 2 alpha. Brain. 133(Pt 4):983-995, 2010.

[79] Bar EE, Lin A, Mahairaki V, Matsui W, Eberhart CG. Hypoxia increases the expression of stem-cell markers and promotes clonogenicity in glioblastoma neurospheres. Am J Pathol. 177:1491-1502, 2010.

[80] Soeda A, Park M, Lee D, Mintz A, Androutsellis-Theotokis A, McKay RD, Engh J, Iwama T, Kunisada T, Kassam AB, Pollack IF, Park DM. Hypoxia promotes expansion of the CD133-positive glioma stem cells through activation of HIF1alpha. Oncogene. 28: 3949-3959, 2009.

[81] Gustafsson MV, Zheng X, Pereira T, Gradin K, Jin S, Lundkvist J, Ruas JL, Poellinger L, Lendahl $U$, Bondesson $M$. Hypoxia requires notch signaling to maintain the undifferentiated cell state. Dev Cell.9:617-628, 2005.

[82] Heddleston JM, Li Z, McLendon RE, Hjelmeland AB, Rich JN. The hypoxic microenvironment maintains glioblastoma stem cells and promotes reprogramming towards a cancer stem cell phenotype. Cell Cycle. 8:3274-3284, 2009.

[83] Cayuso J, Ulloa F, Cox B, Briscoe J, Martí E. The Sonic hedgehog pathway independently controls the patterning, proliferation and survival of neuroepithelial cells by regulating Gli activity. Development. 133(3):517-528, 2006. 
[84] Fuccillo M, Joyner AL, Fishell G. Morphogen to mitogen: the multiple roles of hedgehog signalling in vertebrate neural development. Nat Rev Neurosci. 7(10):772-783, 2006.

[85] Palma V, Lim DA, Dahmane N, Sánchez P, Brionne TC, Herzberg CD, Gitton Y, Carleton A, Alvarez-Buylla A. Ruiz i Altaba A. Sonic hedgehog controls stem cell behavior in the postnatal and adult brain. Development 132(2):335-344, 2005.

[86] Po A, Ferretti E, Miele E, De Smaele E, Paganelli A, Canettieri G, Coni S, Di Marcotullio L, Biffoni M, Massimi L, Di Rocco C, Screpanti I, Gulino A. Hedgehog controls neural stem cells through p53-independent regulation of Nanog. Embo J. 29:26462658, 2010.

[87] Clement V, Sanchez P, de Tribolet N, Radovanovic I, Ruiz i Altaba A. HEDGEHOGGLI1 signaling regulates human glioma growth, cancer stem cell self-renewal, and tumorigenicity. Curr Biol. 17:165-172, 2007.

[88] Zbinden M, Duquet A, Lorente-Trigos A, Ngwabyt SN, Borges I, Ruiz i Altaba, A. NANOG regulates glioma stem cells and is essential in vivo acting in a crossfunctional network with GLI1 and p53. Embo J. 29:2659-2674, 2010.

[89] Stecca B, Ruiz i Altaba, A. A GLI1-p53 inhibitory loop controls neural stem cell and tumour cell numbers. Embo J. 28:663-676, 2009.

[90] MassaguéJ. (2008). TGFbeta in cancer. Cell. 134:215-230.

[91] Shi Y, Massagué J. Mechanisms of TGF-beta signaling from cell membrane to the nucleus. Cell. 113:685-700, 2003.

[92] Xu RH, Sampsell-Barron TL, Gu F, Root S, Peck RM, Pan G, Yu J, Antosiewicz-Bourget J, Tian S, Stewart R, Thomson JA. NANOG is a direct target of GFbeta/activinmediated SMAD signaling in human ESCs. Cell Stem Cell. 3(2):196-206, 2008.

[93] Moustakas A, Heldin CH. Non-Smad TGF-beta signals. J Cell Sci. 118:3573-3584, 2005.

[94] Zhao S, Venkatasubbarao K, Lazor JW, Sperry J, Jin C, Cao L, Freeman JW. Inhibition of STAT3 Tyr705 phosphorylation by Smad4 suppresses transforming growth factor beta-mediated invasion and metastasis in pancreatic cancer cells. Cancer Res. 68:4221-4228, 2008.

[95] Penuelas S, Anido J, Prieto-Sanchez RM, Folch G, Barba I, Cuartas I, Garcia-Dorado D, Poca MA, Sahuquillo J, Baselga J, Seoane J. TGF-beta increases glioma-initiating cell self-renewal through the induction of LIF in human glioblastoma. Cancer Cell. 15:315-327, 2009.

[96] Sherry MM, Reeves A, Wu JK, Cochran BH. STAT3 is required for proliferation and maintenance of multipotency in glioblastoma stem cells. Stem Cells. 27:2383-2392, 2009.

[97] Li GH, Wei H, Lv SQ, Ji H, Wang DL. Knockdown of STAT3 expression by RNAi suppresses growth and induces apoptosis and differentiation in glioblastoma stem cells. Int J Oncol. 37:103-110, 2010.

[98] Wang H, Lathia JD, Wu Q, WangJ, Li Z, Heddleston JM, Eyler CE, Elderbroom J, Gallagher J, Schuschu J, MacSwords J, Cao Y, McLendon RE, Wang XF, Hjelmeland $\mathrm{AB}$, Rich JN. Targeting interleukin 6 signaling suppresses glioma stem cell survival and tumor growth. Stem Cells. 27:2393-2404, 2009. 
[99] Ikushima H, Todo T, Ino Y, Takahashi M, Miyazawa K, Miyazono K. Autocrine TGFbeta signaling maintains tumorigenicity of glioma-initiating cells through Sryrelated HMG-box factors. Cell Stem Cell. 5:504-514, 2009.

[100]Gangemi RM, Griffero F, Marubbi D, Perera M, Capra MC, Malatesta P, Ravetti GL, Zona GL, Daga A, Corte G. SOX2 silencing in glioblastoma tumor-initiating cells causes stop of proliferation and loss of tumorigenicity. Stem Cells. 27:40$48,2009$.

[101] Lee J, Son MJ, Woolard K, Donin NM, Li A, Cheng CH, Kotliarova S, Kotliarov Y, Walling J, Ahn S, Kim M, Totonchy M, Cusack T, Ene C, Ma H, Su Q, Zenklusen JC, Zhang W, Maric D, Fine HA. Epigenetic-mediated dysfunction of the bone morphogenetic protein pathway inhibits differentiation of glioblastoma-initiating cells. Cancer Cell. 13:69-80, 2008.

[102] Mazzoleni S, Politi LS, Pala M, Cominelli M, Franzin A, Sergi Sergi L, Falini A, De Palma M, Bulfone A, Poliani PL, Galli R. Epidermal growth factor receptor expression identifies functionally and molecularly distinct tumor-initiating cells in human glioblastoma multiforme and is required for gliomagenesis. Cancer Res. 70:7500-7513, 2010.

[103]Soeda A, Inagaki A, Oka N, Ikegame Y, Aoki H, Yoshimura S, Nakashima S, Kunisada T, Iwama T. Epidermal growth factor plays a crucial role in mitogenic regulation of human brain tumor stem cells. J Biol Chem. 283:1095810966, 2008.

[104] Griffero F, Daga A, Marubbi D, Capra MC, Melotti A, Pattarozzi A, Gatti M, Bajetto A, Porcile C, Barbieri F, Favoni RE, Lo Casto M, Zona G, Spaziante R, Florio T, Corte G. Different response of human glioma tumor-initiating cells to epidermal growth factor receptor kinase inhibitors. J Biol Chem. 284:7138-7148, 2009.

[105] Eyler CE, Foo WC, LaFiura KM, McLendon RE, Hjelmeland AB, Rich JN. Brain cancer stem cells display preferential sensitivity to Akt inhibition. Stem Cells. 26:30273036, 2008.

[106] Sunayama J, Matsuda K, Sato A, Tachibana K, Suzuki K, Narita Y, Shibui S, Sakurada K, Kayama T, Tomiyama A, Kitanaka C. Crosstalk between the $\mathrm{PI} 3 \mathrm{~K} / \mathrm{mTOR}$ and MEK/ERK pathways involved in the maintenance of selfrenewal and tumorigenicity of glioblastoma stem-like cells. Stem Cells. 28:19301939, 2010.

[107] Levens DL. Reconstructing MYC. Genes Dev. 17:1071-1077, 2003.

[108] Davis AC, Wims M, Spotts GD, Hann SR, Bradley A. A null c-myc mutation causes lethality before 10.5 days of gestation in homozygotes and reduced fertility in heterozygous female mice. Genes Dev. 7(4):671-682, 1993.

[109] Guney I, Wu S, Sedivy JM. Reduced c-Myc signaling triggers telomere-independent senescence by regulating Bmi-1 and p16(INK4a). Proc Natl Acad Sci U S A. 103:3645-3650, 2006.

[110] Wang J, Wang H, LiZ, Wu Q, Lathia JD, McLendon RE, Hjelmeland AB, Rich JN. cMyc is required for maintenance of glioma cancer stem cells. PLoS One. 3:e3769, 2008 . 
[111] Zheng H, Ying H, Yan H, Kimmelman AC, Hiller DJ, Chen AJ, Perry SR, Tonon G, Chu GC, Ding Z, Stommel JM, Dunn KL, Wiedemeyer R, You MJ, Brennan C, Wang YA, Ligon KL, Wong WH, Chin L, DePinho RA. p53 and Pten control neural and glioma stem/progenitor cell renewal and differentiation. Nature. 455:1129-1133, 2008.

[112] Schafer MK, Altevogt P. L1CAM malfunction in the nervous system and human carcinomas. Cell Mol Life Sci.67:2425-2437, 2010.

[113] Bao S, Wu Q, Li Z, Sathornsumetee S, Wang H, McLendon RE, Hjelmeland AB, Rich JN. Targeting cancer stem cells through L1CAM suppresses glioma growth. Cancer Res. 68:6043-6048, 2008.

[114] Ligon KL, Huillard E, Mehta S, Kesari S, Liu H, Alberta JA, Bachoo RM, Kane M, Louis DN, Depinho RA, Anderson DJ, Stiles CD, Rowitch DH. Olig2-regulated lineagerestricted pathway controls replication competence in neural stem cells and malignant glioma. Neuron. 53:503-517, 2007.

[115] Lessard J, Sauvageau G. Bmi-1 determines the proliferative capacity of normal and leukaemic stem cells. Nature. 423:255-260, 2003.

[116] Leung C, Lingbeek M, Shakhova O, Liu J, Tanger E, Saremaslani P, Van Lohuizen M, Marino S. Bmi1 is essential for cerebellar development and is overexpressed in human medulloblastomas. Nature. 428:337-341, 2004.

[117] Molofsky AV, Pardal R, Iwashita T, Park IK, Clarke MF, Morrison SJ. Bmi-1 dependence distinguishes neural stem cell self-renewal from progenitor proliferation. Nature. 425:962-967, 2003.

[118] Valk-Lingbeek ME, Bruggeman SWM, van Lohuizen M. Stem cells and cancer: the Polycomb connection. Cell. 118:409-418, 2004.

[119] Widschwendter M, Fiegl H, Egle D, Mueller-Holzner E, Spizzo G, Marth C, Weisenberger DJ, Campan M, Young J, Jacobs I, Laird PW. Epigenetic stem cell signature in cancer. Nat Genet. 39:157-158, 2007.

[120] Abdouh M, Facchino S, Chatoo W, Balasingam V, Ferreira J, Bernier G. BMI1 sustains human glioblastoma multiforme stem cell renewal. J Neurosci. 29:88848896, 2009.

[121] Suva ML, Riggi N, Janiszewska M, Radovanovic I, Provero P, Stehle JC, Baumer K, Le Bitoux MA, Marino D, Cironi L, Marquez VE, Clement V, Stamenkovic I. EZH2 is essential for glioblastoma cancer stem cell maintenance. Cancer Res. 69:9211-9218, 2009.

[122] Hynes RO. Integrins: bidirectional, allosteric signaling machines. Cell. 110: 673-687, 2002.

[123] Whitley M, Treloar H, De Arcangelis A, Georges Labouesse E, Greer CA. The alpha6 integrin subunit in the developing mouse olfactory bulb. J Neurocytol. 34:81-96, 2005.

[124] Lathia JD, Gallagher J, Heddleston JM, Wang J, Eyler CE, Macswords J, Wu Q, Vasanji A, McLendon RE, Hjelmeland AB, Rich JN. Integrin alpha 6 regulates glioblastoma stem cells. Cell Stem Cell. 6:421-432, 2010. 
[125] He KL, Ting AT. A20 inhibits tumor necrosis factor (TNF) alpha-induced apoptosis by disrupting recruitment of TRADD and RIP to the TNF receptor 1 complex in Jurkat T cells. Mol Cell Biol. 22(17):6034-6045, 2002.

[126] Won M, Park KA, Byun HS, Sohn KC, Kim YR, Jeon J, Hong JH, Park J, Seok JH, Kim JM, Yoon WH, Jang IS, Shen HM, Liu ZG, Hur GM. Novel anti-apoptotic mechanism of A20 through targeting ASK1 to suppress TNF-induced JNK activation. Cell Death Differ. 17(12):1830-1841, 2010.

[127] Guo Q, Dong H, Liu X, Wang C, Liu N, Zhang J, Li B, Cao W, Ding T, Yang Z, Zhang $X$. A20 is overexpressed in glioma cells and may serve as a potential therapeutic target. Expert Opin Ther Targets. 13(7):733-741, 2009.

[128] Hjelmeland AB, Wu Q, Wickman S, Eyler C, Heddleston J, Shi Q, Lathia JD, Macswords J, Lee J, McLendon RE, Rich JN. Targeting A20 decreases glioma stem cell survival and tumor growth. PLoS Biol. 8(2):e1000319, 2010.

[129] Stupp R, Mason WP, van den Bent MJ, Weller M, Fisher B, Taphoorn MJ, Belanger K, Brandes AA, Marosi C, Bogdahn U, Curschmann J, Janzer RC, Ludwin SK, Gorlia T, Allgeier A, Lacombe D, Cairncross JG, Eisenhauer E, Mirimanoff RO. Radiotherapy plus concomitant and adjuvant temozolomide for glioblastoma. $\mathrm{N}$ Engl J Med. 352: 987-996, 2005.

[130] Stupp R, Hegi ME, Mason WP, van den Bent MJ, Taphoorn MJ, Janzer RC, Ludwin SK, Allgeier A, Fisher B, Belanger K, Hau P, Brandes AA, Gijtenbeek J, Marosi C, Vecht CJ, Mokhtari K, Wesseling P, Villa S, Eisenhauer E, Gorlia T, Weller M, Lacombe D, Cairncross JG, Mirimanoff RO. Effects of radiotherapy with concomitant and adjuvant temozolomide versus radiotherapy alone on survival in glioblastoma in a randomised phase III study: 5-year analysis of the EORTC-NCIC trial. Lancet Oncol. 10:459-466, 2009.

[131] Wiewrodt D, Nagel G, Dreimuller N, Hundsberger T, Perneczky A, Kaina B. MGMT in primary and recurrent human glioblastomas after radiation and chemotherapy and comparison with p53 status and clinical outcome. Int J Cancer. 122:1391-1399, 2008.

[132] Murat A, Migliavacca E, Gorlia T, Lambiv WL, Shay T, Hamou MF, de Tribolet N, Regli L, Wick W, Kouwenhoven MC, Hainfellner JA, Heppner FL, Dietrich PY, Zimmer Y, Cairncross JG, Janzer RC, Domany E, Delorenzi M, Stupp R, Hegi ME. Stem cell-related "self-renewal" signature and high epidermal growth factor receptor expression associated with resistance to concomitant chemoradiotherapy in glioblastoma. J Clin Oncol. 26:3015-3024, 2008.

[133] Mellor HR, Ferguson DJ, Callaghan R. A model of quiescent tumour microregions for evaluating multicellular resistance to chemotherapeutic drugs. Br J Cancer. 93:302309, 2005.

[134] Liu Y, Perdreau SA, Chatterjee P, Wang L, Kuan SF, Duensing A. Imatinib mesylate induces quiescence in gastrointestinal stromal tumor cells through the CDH1SKP2-p27Kip1 signaling axis. Cancer Res. 68:9015-9023, 2008.

[135] Masunaga S, Ono K, Hori H, Suzuki M, Kinashi Y, Takagaki M, Kasai S, Nagasawa H, Uto Y. Potentially lethal damage repair by total and quiescent tumor cells following various DNA-damaging treatments. Radiat Med. 17:259-264, 1999. 
[136] Ito K, Bernardi R, Morotti A, Matsuoka S, Saglio G, Ikeda Y, Rosenblatt J, Avigan DE, Teruya-Feldstein J, Pandolfi PP. PML targeting eradicates quiescent leukaemiainitiating cells. Nature. 453:1072-1078, 2008.

[137] Guo W, Lasky JL, Chang CJ, Mosessian S, Lewis X, Xiao Y,Yeh JE, Chen JY, IruelaArispe ML, Varella-Garcia M, Wu, H. Multi-genetic events collaboratively contribute to Pten-null leukaemia stem-cell formation. Nature. 453:529-533, 2008.

[138] Bleau AM, Hambardzumyan D, Ozawa T, Fomchenko EI, Huse JT, Brennan CW, Holland EC. PTEN/PI3K/Akt pathway regulates the side population phenotype and ABCG2 activity in glioma tumor stem-like cells. Cell Stem Cell. 4:226-235, 2009.

[139] Nakai E, Park K, Yawata T, Chihara T, Kumazawa A, Nakabayashi H, Shimizu K. Enhanced MDR1 expression and chemoresistance of cancer stem cells derived from glioblastoma. Cancer Invest. 27:901-908, 2009.

[140] Hsieh A, Ellsworth R, Hsieh D. Hedgehog/GLI1 regulates IGF dependent malignant behaviors in glioma stem cells. J Cell Physiol. 226:1118-1127, 2011.

[141] Vellanki SH, Grabrucker A, Liebau S, Proepper C, Eramo A, Braun V, Boeckers T, Debatin KM, Fulda S. Small-molecule XIAP inhibitors enhance gamma-irradiationinduced apoptosis in glioblastoma. Neoplasia. 11:743-752, 2009.

[142] Wang J, Wakeman TP, Lathia JD, Hjelmeland AB, Wang XF, White RR, Rich JN, Sullenger BA. Notch promotes radioresistance of glioma stem cells. Stem Cells. 28:17-28, 2010.

[143] Gilbert CA, Daou MC, Moser RP, Ross AH. Gamma-secretase inhibitors enhance temozolomide treatment of human gliomas by inhibiting neurosphere repopulation and xenograft recurrence. Cancer Res. 70:6870-6879, 2010.

[144] Cao R, Tsukada Y, Zhang Y. Role of Bmi-1 and Ring1A in H2A ubiquitylation and Hox gene silencing. Mol Cell. 20:845-854, 2005.

[145] Facchino S, Abdouh M, Chatoo W, Bernier G. BMI1 confers radioresistance to normal and cancerous neural stem cells through recruitment of the DNA damage response machinery. J Neurosci. 30:10096-10111, 2010.

[146] Kawai M, Breggia AC, Demambro VE, Shen X, Canalis E, Bouxsein ML, Beamer WG, Clemmons DR, Rosen CJ. The Heparin-binding Domain of IGFBP-2 Has Insulinlike Growth Factor Binding-independent Biologic Activity in the Growing Skeleton. J Biol Chem. 286(16):14670-14680, 2011.

[147] Lin Y, Jiang T, Zhou K, Xu L, Chen B, Li G, Qiu X, Zhang W, Song SW. Plasma IGFBP-2 levels predict clinical outcomes of patients with high-grade gliomas. Neuro Oncol. 11:468-476, 2009.

[148] Wang H, Shen W, Huang H, Hu L, Ramdas L, Zhou Y.H, Liao WS, Fuller GN, Zhang $\mathrm{W}$. Insulin-like growth factor binding protein 2 enhances glioblastoma invasion by activating invasion-enhancing genes. Cancer Res. 63:4315-4321, 2003.

[149] Fukushima T, Tezuka T, Shimomura T, Nakano S, Kataoka H. Silencing of insulin-like growth factor-binding protein-2 in human glioblastoma cells reduces both invasiveness and expression of progression-associated gene CD24. J Biol Chem. 282:18634-18644, 2007.

[150] Hsieh D, Hsieh A, Stea B, Ellsworth R. IGFBP2 promotes gliomatumor stem cell expansion and survival. Biochem Biophys Res Commun. 397:367-372, 2010. 
[151] Evers P, Lee PP, DeMarco J, Agazaryan N, Sayre JW, Selch M, Pajonk F. Irradiation of the potential cancer stem cell niches in the adult brain improves progressionfree survival of patients with malignant glioma. BMC Cancer. 10:384, 2010.

[152] Sneddon JB, Werb Z. Location, location, location: the cancer stem cell niche. Cell Stem Cell. 1:607-611, 2007. 


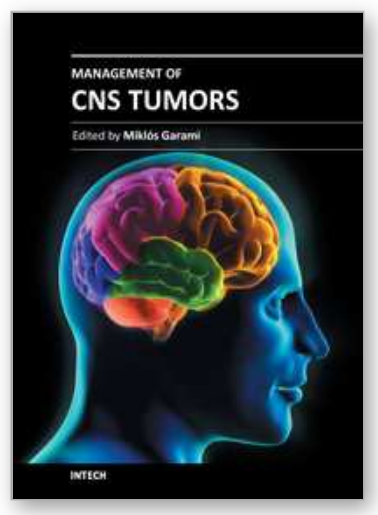

\author{
Management of CNS Tumors \\ Edited by Dr. Miklos Garami
}

ISBN 978-953-307-646-1

Hard cover, 464 pages

Publisher InTech

Published online 22, September, 2011

Published in print edition September, 2011

Management of CNS Tumors is a selected review of Central Nervous System (CNS) tumors with particular emphasis on pathological classification and complex treatment algorithms for each common tumor type. Additional detailed information is provided on selected CNS tumor associated disorders.

\title{
How to reference
}

In order to correctly reference this scholarly work, feel free to copy and paste the following:

Cho-Lea Tso (2011). Molecular Pathways of Glioblastoma and Glioblastoma Stem Cells, Management of CNS Tumors, Dr. Miklos Garami (Ed.), ISBN: 978-953-307-646-1, InTech, Available from:

http://www.intechopen.com/books/management-of-cns-tumors/molecular-pathways-of-glioblastoma-andglioblastoma-stem-cells

\section{INTECH}

open science | open minds

\section{InTech Europe}

University Campus STeP Ri

Slavka Krautzeka 83/A

51000 Rijeka, Croatia

Phone: +385 (51) 770447

Fax: +385 (51) 686166

www.intechopen.com

\section{InTech China}

Unit 405, Office Block, Hotel Equatorial Shanghai

No.65, Yan An Road (West), Shanghai, 200040, China 中国上海市延安西路65号上海国际贵都大饭店办公楼 405 单元

Phone: +86-21-62489820

Fax: $+86-21-62489821$ 
(C) 2011 The Author(s). Licensee IntechOpen. This chapter is distributed under the terms of the Creative Commons Attribution-NonCommercialShareAlike-3.0 License, which permits use, distribution and reproduction for non-commercial purposes, provided the original is properly cited and derivative works building on this content are distributed under the same license. 